\title{
THE FAILED CASE FOR EIGHTH AMENDMENT REGULATION OF THE CAPITAL-SENTENCING TRIAL
}

\author{
SCOTT W. HowE $†$
}

Since banning standardless capital sentencing as "cruel and unusual punishment" in Furman v. Georgia," the Supreme Court has regulated capital-sentencing procedures under the Eighth Amendment. ${ }^{2}$ Many who have written about these efforts have disapproved. ${ }^{3}$ One group of critics has argued for additional or more intensive regulation. These critics have focused on the Court's failure to achieve its stated goal of consistency in capital sentencing. ${ }^{4}$ A different group of critics has lamented the perceived side effects of the Court's regulatory efforts. Such critics have complained, for example, that the Court has unnecessarily disrupted state efforts to impose the death penalty ${ }^{5}$ or has conveyed, through the Justices' frequent failure

† Professor of Law, Chapman University School of Law. A.B. 1977, University of Missouri; J.D. 1981, University of Michigan.

My thanks to Dean Parham H. Williams, Jr., and Associate Dean Larry Putt for institutional support, and to Tony Arnold, Denis Binder, Michael Cohen, Frank Doti, Judith Fischer, Sharon Nantell, Nancy Schultz, and Will Stallworth for valuable comments on previous drafts. Of course, they do not necessarily agree with all of my views expressed in this Article. Most importantly, I thank Jetty Maria Howe for assistance and encouragement at all stages of the project.

I have benefited in the preparation of this Article from a research grant provided by Chapman University School of Law.

408 U.S. 238 (1972) (per curiam).

2 The Eighth Amendment provides: "Excessive bail shall not be required, nor excessive fines imposed, nor cruel and unusual punishments inflicted." U.S. CONST. amend. VIII.

${ }^{3}$ For a thorough and recent critique of the Court's capital-sentencing jurisprudence, see Carol S. Steiker \& Jordan M. Steiker, Sober Second Thoughts: Reflections on Two Decades of Constitutional Regulation of Capital Punishment, 109 HARV. L. REV. 357 (1995).

1 For citations to a sample of such scholarship, see Louis D. Bilionis, Legitimating Death, 91 MiCH. L. REV. 1643, 1647-48 \& nn. 20-22 (1993).

${ }^{5}$ See, e.g., Alex Kozinski \& Sean Gallagher, Death: The Ultimate Run-On Sentence, 46 CASE W. RES. L. REV. 1, 29 (1995) (criticizing the Supreme Court on the ground that "[t] he established application of the Eighth Amendment to the administration of the death penalty will continue to give opponents a legitimate platform from which to impede even the most determined efforts to carry out the death penalty on a routine basis"); Ted Guest, A House Without a Blueprint, U.S. NEWS \& WORLD REP., July 8, 1996, at 41,41 (contending that "[t]he Supreme Court is a prime culprit" in thwarting the will of the citizenry favoring the death penalty through " $[t]$ wo decades of decisions 
to find consensus, a poor message regarding our ability to reconcile social conflicts. ${ }^{6}$ Of the Court's many critics on capital sentencing, however, only a few, at least in recent years, have challenged the Court's basic decision to regulate capital sentencing under the Eighth Amendment. ${ }^{7}$

The scholars who have challenged the propriety of the Court's effort to govern capital sentencing have typically relied on formalist attacks that concede no ground for Eighth Amendment regulation. For example, Professor Raoul Berger, invoking the duty to follow original intent, has emphasized that the Cruel and Unusual Punishments Clause was not understood by its promulgators to govern the process for selecting which capital offenders will die. ${ }^{8}$ Similarly, Justice Thomas has concluded that the Eighth Amendment was originally intended only to place substantive limitations on punishments and that the Court should not have abandoned that original understanding by regulating capital-sentencing procedures. ${ }^{9}$ Chief Justice Rehnquist has reached a similar conclusion that is based, in part, on a view of the plain meaning of the Cruel and Unusual Punishments Clause. ${ }^{10}$

This Article rejects the role of the Court in regulating capital sentencing under the Eighth Amendment on prudential grounds rather

attempting to sort out the rules for executions [that] have left prosecutors and defense lawyers more confused than enlightened"); The Waiting Game, EcoNOMIST, Apr. 1,1995 , at 19,19-20 (noting the views of some observers that the small ratio of executions to death sentences stems in part from Supreme Court rulings on capital sentencing that have resulted in "case law that is inherently unstable and open to challenge").

${ }^{6}$ See, e.g., Robert A. Burt, Disorder in the Cont: The Death Penally and the Constitution, 85 MICH. L. REV. 1741, 1819 (1987) ("The Justices have provided this lesson, though unwittingly, by embodying their conceptions of American society: In conflicts among implacably opposed adversaries, nothing is ever sensibly resolved or learned."):

${ }_{7}$ Although I favor abolition, this Article focuses on the question whether, assuming capital punishment is to be employed, the Eighth Amendment regulates the capital-sentencing trial. For a classic argument for abolition, see CHARLES L. BLACK JR., CAPITAL PUNISHMENT: THE INEVITABILITY OF CAPRICE AND MISTAKE (1974).

${ }^{3}$ See generally RaOUl Berger, DEATH PENALTIES 44-49, 47 (1982) (“[S]pecial safeguards in application of the death penalty were provided by the Fifth Amendment precisely because the Framers postulated that the death penalty was unaffected by the Eighth Amendment.").

9 See Graham v. Collins, 506 U.S. 461, 488 (1993) (Thomas, J., concurring) ("[T]he better view is that the Cruel and Unusual Punishments Clause was intended to place only substantive limitations on punishments, not procedural requirements on sentencing ....").

${ }^{10}$ See Gardner v. Florida, 430 U.S. 349, 371 (1977) (Rehnquist, J., dissenting) ("The prohibition of the Eighth Amendment relates to the character of the punishment, and not to the process by which it is imposed."). 
than based on formalist views about the original understanding or plain meaning of the prohibition against "cruel and unusual punishments." This Article argues that the Eighth Amendment speaks to the question of who can receive the death penalty and does so in terms that should guide the capital sentencer. The Eighth Amendment does not call for consistency among capital offenders, but rather speaks to the substantive standard that defines who may be sentenced to death. The relevant Eighth Amendment command is to avoid imposing the death penalty on those who do not deserve that sanction. Nonetheless, this Article demonstrates that the Supreme Court lacks the capacity to translate this general Eighth Amendment principle into rules for conducting capital-sentencing trials. ${ }^{11}$

This Article advocates Eighth Amendment restrictions on determining who is subject to the death penalty. It concludes, however, that the Court should only draw categorical lines separating deatheligible crimes and offenders on the one hand, and crimes and offenders for which the death penalty is per se improper on the other hand. Rape, for example, is not a death-eligible crime. Similarly,

"The Article does not suggest that the Court has pursued the deserts-limitation principle and failed, for the Court generally has been incoherent about its aim in regulating capital sentencing. Pursuing the deserts-limitation principle in capital sentencing would require the Court to regulate the sentencing proceeding so as to enable and require sentencers to find that the offender deserves death as a prerequisite to a death sentence. See infra Part III. The Court has often cited the elimination of arbitrariness in capital sentencing as its goal. However, this theory is not very helpful without a substantive measure by which to judge what differences among cases matter, and the Court has not provided such a measure. The Court has sometimes stated that the relevant measure is offender "culpability," see, e.g., McKoy v. North Carolina, 494 U.S. 433, 443 (1990) (stating that "the punishment should be directly related to the personal culpability of the defendant" (quoting Penry v. Lynaugh, 492 U.S. 302, 327 (1989))), but has not pursued doctrine consistent with this approach. See infra notes 175-77 and accompanying text; see also Johnson v. Texas, 509 U.S. 350, 373 (1993) (approving a Texas statute that made an offender's probable future dangerousness a dispositive factor in deciding which capital offenders would receive death sentences). For this reason, uncertainty prevails over how to describe what the Court has sought to accomplish through its regulation of capital-sentencing trials. Compare Steiker \& Steiker, supra note 3, at 366-69 (contending that remedying the problem of "underinclusion" - the failure to impose death sentences on some who deserve that sanction-was one of the important goals of the Court in regulating capital sentencing), with David McCord, Judging the Effectiveness of the Supreme Court's Death Penalty Jurispredence According to the Court's Own Goals: Mild Success or Major Disaster?, 24 FLA. ST. U. L. REV. 545, 548 (1997) (contending that "the Court has had only one primary goal for its regulation of capital punishment: decreasing overinclusion, with particular interest in minimizing invidious overinclusion due to racial bias"). The Court's failure to articulate a coherent regulatory theory, however, is a separate problem from the issue of whether overwhelming difficulties are inherent in any efforts to regulate capital-sentencing trials. 
seventeen-year-old offenders are not subject to the death penalty. These are the sorts of conclusions that the Court could legitimately articulate and enforce under the deserts limitation in the Eighth Amendment.

The problem for the Court in pursuing the deserts limitation as a basis for regulating the capital-sentencing trial stems from the inability to identify with substantial precision how to measure offender deserts. The Court cannot define the weight that the capital sentencer should accord various evidentiary factors. Nor can the Court define with much precision what evidence the capital sentencer should consider. The societal consensus in favor of the deserts limitation does not translate into rules at these more exacting levels. Yet, to enforce the deserts limitation at the capital-sentencing trial requires the Court to articulate relatively precise rules. If the Court cannot provide specifics, the Eighth Amendment can no longer justify preventing legislatures from specifying the rules.

My demonstration of the inevitability of failure in attempts at Eighth Amendment regulation of capital-sentencing trials proceeds in four stages. Part I briefly describes the development and contours of the Supreme Court's current capital-sentencing doctrine. Part II then assesses the "nonarbitrariness" or "consistency" theory usually offered by the Court as the justification for this doctrine. The Article demonstrates not only that this theory fails to explain the Court's capital-sentencing holdings, but also, more importantly, that the theory lacks a grounding in the Eighth Amendment. Part III assesses the deserts-limitation principle as a basis for capital-sentencing regulation, and demonstrates that this principle explains certain aspects of the Court's doctrine better than the nonarbitrariness theory. The deserts limitation, stated broadly, also conforms with the Eighth Amendment. The Article argues, however, that the principle does not translate into the sort of rules with which the Court can sensibly regulate capital-sentencing trials. Part IV proposes a limited use of the deserts-limitation principle to articulate bright-line rules defining the boundaries of constitutional application of the death penalty. The Article concludes that the Court has appropriately employed the Eighth Amendment on occasion to promulgate these kinds of restrictions and that its approach to regulating capital punishment should focus on expanding these protections. 


\section{FURMANAND ITS FRUITS: CONSISTENCY AS THE GOAL}

Considered as a prelude to the regulation of capital-sentencing trials, the decision in Furman $v$. Georgia ${ }^{12}$ was spectacularly flawed. If the prohibition on cruel and unusual punishments was used appropriately to narrow the number of death-eligible crimes and offenders, standardless capital sentencing should not violate the Eighth Amendment. Indeed, the Court's current doctrine has effectively endorsed standardless discretion by the sentencer at the ultimate stage of choosing between imprisonment and death. The inability to distinguish a just from an unjust death sentence has prevented the Court from prescribing standards that actually guide the sentencer's decision. Yet this very inability to define a just death sentence calls into question the basic legitimacy of the Court's project to regulate capital-sentencing trials under the Eighth Amendment.

\section{A. Furman and the 1976 Cases}

The meaning of the per curiam order in Furman is elusive. In Furman, the Supreme Court, for the first time, used the Eighth Amendment to strike down a capital sentence. ${ }^{13}$ The splintered, fiveJustice majority clearly condemned standardless capital sentencing. However, the majority offered little guidance regarding what sort of sentencing systems would pass muster. Two majority JusticesBrennan and Marshall-believed the death penalty unconstitutional in all circumstances. ${ }^{14}$ The three other majority Justices-Douglas, Stewart, and White-did little to clarify what kind of systems the Eighth Amendment would allow, beyond separately expressing their dissatisfaction with standardless sentencing schemes. Each of these three Justices appeared to strike a blow against "arbitrary" and "capricious" sentencing systems, ${ }^{15}$ but that prohibition carried an

12408 U.S. 238 (1972) (per curiam).

13 See id. at 239-40 (per curiam) ("The Court holds that the imposition and carrying out of the death penalty in these cases constitute cruel and unusual punishment in violation of the Eighth and Fourteenth Amendments.").

${ }^{14}$ See id. at 305 (Brennan, J., concurring) ("The punishment of death is ... 'cruel and unusual' punishment and the States may no longer inflict it as a punishment for crimes."); id. at 359 (Marshall, J., concurring) ("There is no rational basis for concluding that capital punishment is not excessive. It therefore violates the Eighth Amendment.").

${ }^{15}$ See id. at 256-57 (Douglas, J., concurring) ("[T]hese discretionary statutes are ... pregnant with discrimination and discrimination is an ingredient not compatible with the idea of equal protection of the laws that is implicit in the ban on "cruel 
accordion-like range of potential meanings. Were states that desired to use the death penalty required to make it mandatory for all capital offenders? Were they instead only required to provide relatively precise standards to govern the capital-sentencing decision? Or could they simply narrow the group subject to the death penalty while granting the sentencer unfettered discretion to impose either death or imprisonment for that smaller group?

Four years after Furman, the Court revisited the question of Furman's meaning in a well-known quintet of decisions. ${ }^{16}$ Nearly twothirds of the states had promptly enacted new death-penalty statutes after 1972. ${ }^{17}$ Their responses to Furman were of two kinds. The majority of these states adopted legislation making the death penalty mandatory upon conviction for a capital offense. ${ }^{18}$ The minority adopted statutes providing for a capital-sentencing hearing with standards. ${ }^{19}$ In the 1976 cases, the Supreme Court upheld statutes from Florida, Georgia, and Texas that provided for capital-sentencing

and unusual' punishments."); $i d$. at 309-10 (Stewart, J., concurring) ("[O]f all the people convicted of rapes and murders in 1967 and 1968, many just as reprehensible as these, the petitioners are among a capriciously selected random handful upon whom the sentence of death has in fact been imposed." (footnote omitted)); id at 313 (White, J., concurring) ("[T]he death penalty is exacted with great infrequency even for the most atrocious crimes and ... there is no meaningful basis for distinguishing the few cases in which it is imposed from the many cases in which it is not.").

${ }^{16}$ The decision in each case was issued on July 2, 1976. See Roberts v. Louisiana, 428 U.S. 325 (1976) (considering a Louisiana statute mandating the death penalty for convicted first-degree murderers); Woodson v. North Carolina, 428 U.S. 280 (1976) (considering North Carolina's mandatory death-penalty statute for first-degree murderers); Jurek v. Texas, 428 U.S. 262 (1976) (considering a Texas statute that limited the definition of capital homicides and required the jury to answer three special questions in the affirmative before the death penalty could be imposed); Proffitt $v$. Florida, 428 U.S. 242 (1976) (considering a Florida statute requiring the trial.judge to weigh aggravating factors against mitigating factors in order to decide whether the death penalty should be imposed); Gregg v. Georgia, 428 U.S. 153 (1976) (considering a Georgia statute that required the judge or jury to consider aggravating and mitigating factors before imposing the death penalty).

${ }^{17}$ Thirty-five states passed new death-penalty statutes after Furman and before the Supreme Court ruled on these new efforts in 1976. See John W. Poulos, The Supreme Court, Capital Punishment and the Substantive Criminal Law: The Rise and Fall of Mandatory Capital Punishment, 28 ARIZ. L. REV. 143, 226, 238 tbl.1 (1986).

${ }_{18}$ Twenty-two of the 35 states enacted statutes mandating the death penalty upon conviction. See id. at 227, 238 tbl.1. These legislative mandates varied according to the manner in which they defined the capital offense(s) involved. See id. at 200-26.

${ }^{19}$ The standards employed varied substantially from state to state. See generally Note, Discretion and the Constitutionality of the New Death Penalty Statutes, 87 HARV. L. REV. 1699-709 (1974) (discussing post-Furman death-penalty statutes and describing the various standards they imposed to limit discretion). 
hearings with standards. ${ }^{20}$ At the same time, the Court struck down statutes from Louisiana and North Carolina mandating the death penalty upon conviction. ${ }^{21}$

At the rhetorical level, the opinions supporting these decisions portrayed Furman's holding as requiring that capital sentences be administered to promote consistency. For example, in upholding the Georgia statute in Gregg v. Georgia, Justice Stewart, writing for himself and two other Justices, reiterated that Furman stood for the proposition that the death penalty "could not be imposed under sentencing procedures that created a substantial risk that it would be inflicted in an arbitrary and capricious manner." ${ }^{22}$ Justice White, in endorsing the Georgia statute, implied that Furman had required that a capitalsentencing system "result in death sentences being imposed with reasonable consistency." ${ }^{23}$ Likewise, in Woodson v. North Carolina, Justice Stewart, for a plurality, asserted that Furman had required that states replace "arbitrary and wanton jury discretion with objective standards to guide, regularize, and make rationally reviewable the process for imposing a sentence of death." ${ }^{24}$ This kind of language in the opinions in the 1976 cases constructed a view that Furman required substantial equality in the distribution of death sentences among convicted capital offenders. ${ }^{25}$

${ }^{20}$ See Proffitt, 428 U.S. at 259-60 (plurality opinion) (upholding the Florida statute because " $[t]$ hat legislation provides that after a person is convicted of first-degree murder, there shall be an informed, focused, guided, and objective inquiry into the question whether he should be sentenced to death"); Gregg, 428 U.S. at 206-07 (plurality opinion) (upholding the Georgia statute because it allowed the jury to give individualized consideration of defendants based on certain standards); Jurek, 428 U.S. at 276 (plurality opinion) (upholding the Texas statute because, "[b]y narrowing its definition of capital murder, Texas has essentially said that there must be at least one statutory aggravating circumstance in a first-degree murder case before a death sentence may even be considered" and the state allowed presentation of mitigating factors).

${ }^{21}$ See Woodson, 428 U.S. at 302-05 (plurality opinion) (striking down the North Carolina statute due to its failure to provide standards to guide a jury's decision to impose the death penalty and to allow individualized consideration of defendants); Roberts, 428 U.S. at 335-36 (plurality opinion) (holding that the Louisiana mandatory death-penalty statute was unconstitutional on grounds similar to those in Woodson).

${ }^{22} 428$ U.S. at 188 (plurality opinion).

${ }^{2 s}$ Id. at 222 (White, J., concurring in judgment).

24428 U.S. at 303 (plurality opinion).

${ }^{25}$ The Court has continued to portray Furman as requiring an acceptable pattern representing the divide between those who receive the death penalty and those who are spared. See, e.g., Lewis v. Jeffers, 497 U.S. 764, 774 (1990) (noting that states must "'make rationally reviewable the process for imposing a sentence of death"' (quoting 
At first blush, the Court's approval of the statutes from Florida, Georgia, and Texas also appeared consistent with the Justices' rhetoric regarding the meaning of Furman. In Gregg, the Court upheld a Georgia system that required the capital sentencer to find an aggravating factor from a statutory list before proceeding to a discretionary decision between imprisonment and death. ${ }^{26}$ Gregg argued that this system would not lead to consistent results because it did not guide the jury's ultimate decision. ${ }^{27}$ However, the Court rejected Gregg's contention, based in part on a provision in the statute requiring the Georgia Supreme Court to review all Georgia death sentences to ensure consistency of application. ${ }^{28}$ Although the Florida statute did not provide for such appellate review, that system required a more elaborate balancing by capital sentencers of statutory lists of aggravators and mitigators before the imposition of a death sentence. ${ }^{29}$ Likewise, the Texas system actually guided the sentencer's decision based on three "special issue" questions. ${ }^{\text {so }}$ Thus, the three systems

Godfrey v. Georgia, 446 U.S. 420, 428 (1980) (plurality opinion) (quoting Woodson, 428 U.S. at 303 (plurality opinion)))).

${ }^{26}$ See Gregg, 428 U.S. at $164-65$ (plurality opinion) ("Before a convicted defendant may be sentenced to death ... the jury, or the trial judge in cases tried without a jury, must find beyond a reasonable doubt one of the 10 aggravating circumstances specified in the statute.").

${ }^{27}$ See id. at 203 (plurality opinion).

${ }^{23}$ See id. at 204 (plurality opinion).

29 See Proffitt v. Florida, 428 U.S. 242, 249-50 (1976) (plurality opinion) (discussing the capital-sentencing procedure required by the post-Furman Florida statute).

${ }^{\text {so }}$ See Jurek v. Texas, 428 U.S. 262, 269 (1976) (plurality opinion).

The Texas statute required the sentencing jury or judge to answer the following specific questions:

(1) whether the conduct of the defendant that caused the death of the deceased was committed deliberately and with the reasonable expectation that the death of the deceased or another would result;

(2) whether there is a probability that the defendant would commit criminal acts of violence that would constitute a continuing threat to society; and

(3) if raised by the evidence, whether the conduct of the defendant in killing the deceased was unreasonable in response to the provocation, if any, by the deceased.

TEX. CODE CRIM. P. ANN. art. 37.071 (b) (West 1981). The Texas legislature amended the statute after the Supreme Court, in Penry v. Lynaugh, 492 U.S. 302, 320-28 (1989), held it unconstitutional as applied to a mentally retarded offender with a background of abuse.

The new Texas statute poses two questions similar to the first two questions in the old statute and also, as a precondition to a death sentence, requires the sentencer to answer negatively the following broad question:

Whether, taking into consideration all of the evidence, including the circumstances of the offense, the defendant's character and background, and the personal moral culpability of the defendant, there is a sufficient mitigat- 
that the Court approved gave some appearance of promoting consistency in the treatment of convicted capital offenders.

The crucial plurality Justices-Stewart, Powell, and Stevens-also portrayed the rejection of the mandatory death statutes from North Carolina and Louisiana as promoting consistency. ${ }^{31}$ A mandatory death statute treats convicted capital offenders uniformly by requiring the death penalty for all of them. The plurality contended, however, that uniform treatment of convicted offenders was inequitable because differences existed among them ${ }^{32}$ and those differences justified sparing some convicted capital offenders from the death

ing circumstance or circumstances to warrant that a sentence of life imprisonment rather than a death sentence be imposed.

TEX. CODE CRIM. P. ANN. art. 37.071(2) (e) (West Supp. 1998).

${ }^{31}$ See Woodson v. North Carolina, 428 U.S. 280, 303 (1976) (plurality opinion)

("While a mandatory death penalty statute may reasonably be expected to increase the number of persons sentenced to death, it does not fulfill Furman's basic requirement by replacing arbitrary and wanton discretion with objective standards to guide, regularize, and make rationally reviewable the process for imposing a sentence of death."); Roberts v. Louisiana, 428 U.S. 325, 334 (1976) (plurality opinion) ("Louisiana's mandatory death sentence statute also fails to comply with Furman's requirement that standardless jury discretion be replaced by procedures that safeguard against the arbitrary and capricious imposition of death sentences.").

The plurality also relied on two other grounds to reject the mandatory death statutes. First, the plurality contended that the mandatory death statutes conflicted with the legislative rejection of such statutes beginning in the middle of the 19th century. See Woodson, 428 U.S. at 295 (plurality opinion) ("The consistent course charted by the state legislatures and by Congress since the middle of the past century demonstrates that the aversion of jurors to mandatory death penalty statutes is shared by society at large."). Second, the plurality asserted that the mandatory death statutes caused jurors to acquit persons otherwise guilty of the capital offense and, thus, merely shifted the locus of arbitrary action to the guilt-or-innocence trial. See id. at 302 (plurality opinion) (" $[\mathrm{T}]$ here is general agreement that American juries have persistently refused to convict a significant portion of persons charged with first-degree murder of that offense under mandatory death penalty statutes."). These arguments failed to acknowledge that most death-penalty states viewed mandatory statutes as the best choice after Furman, see Poulos, supra note 17, at 227, 238 tbl.1 (indicating that 22 of the 35 states that enacted new death-penalty statutes between 1972 and 1976 adopted statutes mandating the death penalty upon conviction), and that systems like Georgia's, which the Court approved, allowed for much arbitrariness at sentencing, see, e.g., Zant v. Stephens, 462 U.S. 862, 875 (1983) (conceding that the Georgia scheme upheld in Gregg allowed a jury "unbridled discretion in determining whether the death penalty should be imposed" once the jury had identified a single aggravating circumstance).

${ }^{32}$ See Woodson, 428 U.S. at 30406 (plurality opinion) (arguing that the fundamental respect for humanity underlying the Eighth Amendment requires individual consideration of each offender). 
penalty. ${ }^{33}$ The North Carolina statute was limited to those guilty of either premeditated killing or a killing committed during certain felony crimes, ${ }^{34}$ and the Louisiana statute applied to an even narrower category of murders. ${ }^{35}$ The plurality Justices concluded, however, that it was improper even to reserve the mandatory death penalty for those guilty of limited categories of aggravated murder. ${ }^{36}$ Separating the group to be executed from one which should be spared could only be accomplished through an inquiry providing "consideration of the character and record of the individual offender and the circumstances of the particular offense. ${ }^{37}$ The plurality did not clarify which facets of an individual's background and crime were relevant. However, the mandatory death statutes before the Court allowed for consideration of almost no factors and so could not pass muster. ${ }^{38}$

\section{B. Lockett and the Broad Individualization Rule}

The Court soon addressed what information the capital offender must remain free to present and in what ways the capital sentencer must be free to use the information to reject a death sentence. Was the sentencer to resolve what punishment the offender deserved, or, instead, a more utilitarian question, such as whether the offender

${ }^{33}$ See id. at 305 n.39 (plurality opinion) (implying that the death penalty is inappropriate in some cases depending on "the circumstances of the crime and the character and record of the offender ${ }^{n}$ ).

${ }^{34}$ Under the North Carolina statute covering murder, only those guilty of firstdegree murder were subject to the mandatory death statute. See id. at 286-87 (plurality opinion). First-degree murder was defined to include premeditated killings and those killings committed in the course of certain enumerated felonies. See id. at 286 (plurality opinion). North Carolina also enacted a statute shortly after Furman mandating the death penalty for first-degree rape. See id. at $287 \mathrm{n.6}$ (plurality opinion).

${ }^{35}$ In Louisiana, the mandatory death statute also applied to first-degree murder, but that crime was limited to five relatively specific categories of homicide and was defined so as to require proof in four of the five cases that the defendant had the "specific intent to kill or to inflict great bodily harm." Roberts, 428 U.S. at 329 n.3 (plurality opinion).

${ }^{56}$ See id. at 332 (plurality opinion) ("That Louisiana has adopted a different and somewhat narrower definition of first-degree murder than North Carolina is not of controlling constitutional significance.").

${ }^{37}$ Woodson, 428 U.S. at 304 (plurality opinion).

${ }^{s 8}$ See id. (plurality opinion) (concluding that the North Carolina statute "excludes from consideration in fixing the ultimate punishment of death the possibility of compassionate or mitigating factors stemming from the diverse frailties of humankind"); Roberts, 428 U.S. at 333 (plurality opinion) ("The constitutional vice of mandatory death sentence statutes-lack of focus on the circumstances of the particular offense and the character and propensities of the offender-is not resolved by Louisiana's limitation of first-degree murder to various categories of killings."). 
posed a future danger? ${ }^{39}$ Although the Court did not define the substantive focus of the sentencing inquiry, a plurality ruled broadly, in Lockett v. Ohio, that the capital sentencer must remain free to consider any evidence that the capital offender proffers that relates to the offender's character, record, or crime. ${ }^{40}$ On this basis, the Court invalidated an Ohio statute that limited the sentencer to reprieving the capital offender on only three narrow grounds. ${ }^{41}$ While the Court inquiries:

${ }^{39}$ Professor Garvey has described the difference between these two kinds of

Retributivism holds that punishment is justified when it is deserved.... [R] etributivism is deontological and backward-looking. In contrast to forward-looking consequentialist approaches that justify punishment in the name of what might be, retributivism justifies punishment in the name of what has been. Punishment strictly predicated on moral desert is blind to the future.

Stephen P. Garvey, "As the Gentle Rain from Heaven": Mercy in Capital Sentencing, 81 CORNELL L. REV. 989, 1012 (1996).

${ }^{40}$ See 438 U.S. 586, 604 (1978) (plurality opinion) ("[W]e conclude that the Eighth and Fourteenth Amendments require that the sentencer, in all but the rarest kind of capital cases, not be precluded from considering, as a mitigating factor, any aspect of a defendant's character or record and any of the circumstances of the offense that the defendant proffers as a basis for a sentence less than death." (footnote omitted)); see also id. at 620-21 (Marshall, J., concurring in judgment) ("The Ohio statute, with its blunderbuss, virtually mandatory approach to imposition of the death penalty for certain crimes, wholly fails to recognize the unique individuality of every criminal defendant who comes before its courts.").

Although Locketh, in dealing with the constitutionality of the mandatory death sentence imposed in that case, was decided by a four-Justice plurality with Justice Marshall in concurrence, the five Justices agreed that the Ohio statute had precluded adequate consideration of mitigating evidence. See id. at 606 (plurality opinion) ("The Ohio death penalty statute does not permit the type of individualized consideration of mitigating factors we now hold to be required by the Eighth and Fourteenth Amendments in capital cases."); id. at 620 (Marshall, J., concurring in judgment) ("As the plurality points out, petitioner was sentenced to death under a statutory scheme that precluded any effective consideration of her degree of involvement in the crime, her age, or her prospects for rehabilitation."). Justice Marshall declined to join the plurality opinion to avoid suggesting that the death penalty was sometimes constitutional. See id. at 621 (Marshall, J., concurring in judgment) ("I do not ... join in the Court's assumption that the death penalty may ever be imposed without violating the command of the Eighth Amendment that no 'cruel and unusual punishments' be imposed.").

"The statute mandated the death penalty unless,

"considering the nature and circumstances of the offense and the history, character, and condition of the offender, one or more of the following [was] established by a prepondence [preponderance] of the evidence:

(1) The victim of the offense induced or facilitated it.

(2) It is unlikely that the offense would have been committed, but for the fact that the offender was under duress, coercion, or strong provocation. 
had only recently approved the Texas system, under which the capital sentencer also could reprieve the offender on only three grounds, ${ }^{42}$ the Court found the Ohio questions overly restrictive. ${ }^{48}$ The Ohio statute did not allow the capital sentencer to give mitigating weight to such evidence as an offender's youth or minor participation in the capital crime. ${ }^{44}$

In subsequent decisions, the Court has generally remained committed to Lockett's broad individualization rule. In the decade after Lockett, the Court reversed death sentences whenever trial courts precluded consideration of mitigating evidence regarding the offender or her crime. ${ }^{45}$ These decisions involved evidence related to several substantive issues. Some related to the offender's lack of

(3) The offense was primarily the product of the offender's psychosis or mental deficiency, though such condition is insufficient to establish the defense of insanity."

Id. at 612-13 (appendix to opinion of the Court) (second alteration in original) (quoting OHIO REV. CODE ANN. § 2929.04(B) (1975)).

${ }^{12}$ For the text of the three questions in the Texas statute, see supra note 30.

${ }^{43}$ See supra note 40.

${ }^{44}$ On the same date, the Court also reversed a death sentence in another Ohio case on the ground that the same statute failed to enable the sentencer to reject the capital punishment based on such factors as the defendant's low intelligence, emotional disturbance, youth, and troubled and violent upbringing. See Bell v. Ohio, 438 U.S. 637, 641-43 (1978) (plurality opinion).

${ }^{45}$ See, e.g., Hitchcock v. Dugger, 481 U.S. 393, 397-99 (1987) (ruling that the list of mitigating factors in a state statute, when interpreted by the trial judge as exclusive, prevented consideration of, among other things, evidence that the defendant had suffered possible brain damage from sniffing gasoline during adolescent years, had been raised in conditions of gross social adversity, and had been a "fond and affectionate uncle"); Skipper v. South Carolina, 476 U.S. 1, 5-6 (1986) (reversing the exclusion by the trial judge of evidence that the defendant had been well-behaved in jail to show not merely a positive aspect of the defendant's character, but also that he would pose no undue danger to others in prison and could lead a useful life behind bars if sentenced to life imprisonment); Eddings v. Oklahoma, 455 U.S. 104, 113 (1982) (holding that the interpretation of the sentencing statute by the sentencing judge as not permitting consideration of evidence of the defendant's emotional disturbance, and troubled and violent upbringing violated the Lockett rule); see also Mills v. Maryland, 486 U.S. 367, 370-71, 384 (1988) (stating that the trial judge's jury instructions might mislead the jurors into thinking that the death-penalty statute required that particular mitigating factors be found unanimously before being given consideration, which precluded adequate consideration of evidence of the defendant's relative youth and mental infirmity); cf. McKoy v. North Carolina, 494 U.S. 433, 439-44 (1990) (holding that a statutory requirement that a jury unanimously find mitigating circumstances before giving them consideration precluded adequate consideration of, among other things, evidence of the defendant's emotional disturbance and age). 
future dangerousness. ${ }^{46}$ Some related to the offender's responsibility for the capital offense. ${ }^{47}$ Some revealed the offender's good acts unrelated to the capital offense. ${ }^{48}$ The Court also implied that where evidence potentially served more than one mitigating function, the sentencer should remain free to consider it for any of several proffered purposes. ${ }^{49}$ In 1989, the Court even invalidated, as applied to a mentally retarded and abused offender, the three-question system from Texas that it had upheld in $19766^{50}$ The Court found that, although the evidence of mental retardation and abuse bore on the offender's moral responsibility, the Texas statutory questions did not allow the sentencer to give the evidence mitigating weight. ${ }^{51}$

${ }^{46}$ See, e.g., Skipper, 476 U.S. at 5-6 (focusing on evidence of the defendant's good behavior in jail when proffered to prove defendant's likely favorable adjustment in prison if spared from death).

${ }^{4}$ See, e.g., McKoy, 494 U.S. at 439-44 (invalidating requirement that jury find mitigating circumstances unanimously before giving them mitigating weight because it impeded adequate consideration of the defendant's age and emotional disturbance); Mills, 486 U.S. at 370-71, 384 (invalidating the death sentence imposed as a result of possible misinterpretation by the jury that the death-penalty statute required mitigating circumstances be found unanimously by jury before receiving mitigating weight because it precluded adequate consideration of mitigating evidence, which included the defendant's youthfulness and mental disability); Hitchcock, 481 U.S. at 397-99 (rejecting practice of limiting potential mitigating factors to those on the statutory list which precluded from consideration the defendant's apparent mental disabilities caused by sniffing gasoline as a youth and the defendant's upbringing in conditions of social and financial poverty); Eddings, 455 U.S. at 110 (rejecting trial court's interpretation of sentencing statute because it prohibited consideration of evidence of the defendant's emotional disturbance, turbulent upbringing, and background of abuse).

${ }^{49}$ See Hitchcock, 481 U.S. at 397-99 (ruling that the jury must be allowed to consider mitigating factors not on the statutory list and implying that evidence that the defendant was a "fond and affectionate uncle" could be considered).

${ }^{49}$ The Court made this point in its opinion in Skipper.

[A] defendant's disposition to make a well-behaved and peaceful adjustment to life in prison is itself an aspect of his character that is by its nature relevant to the sentencing determination.... Assuming, however, that the [state's] rule would in any case have the effect of precluding the defendant from introducing otherwise admissible evidence for the explicit purpose of convincing the jury that he should be spared the death penalty because he would pose no undue danger to his jailers or fellow prisoners and could lead a useful life behind bars if sentenced to life imprisonment, the rule would not pass muster under Eddings.

Skipper, 476 U.S. at 7.

${ }^{50}$ See Penry v. Lynaugh, 492 U.S. 302, 328 (1989) (" $[W]$ e conclude that the jury was not provided with a vehicle for expressing its 'reasoned moral response' to that evidence in rendering its sentencing decision.").

${ }^{51}$ See id. at 320-28 (discussing the three-question system and its implications for evidence presented in the instant case). 


\section{The Narrowing Requirement}

It has become clear during the last two decades that the broad individualization mandate only works effectively under a sentencing scheme that allows the sentencer unfettered choice between death and imprisonment at the final stage of decisionmaking. This reality poses no problem for existing capital-sentencing systems because all existing systems simply narrow the group of capital offenders subject to a discretionary decision based on the parties' evidentiary presentations. ${ }^{52}$ The narrowing function is accomplished by merely requiring the jury at the guilt-or-innocence stage of the trial or the sentencer to identify at least one aggravating factor from a statutory list. This requirement is a prerequisite to the final stage of discretionary decisionmaking by the sentencer. In fact, the Supreme Court endorsed this approach in 1976 when it approved the Florida and Georgia systems. ${ }^{53}$ Although the Court at the time had erroneously characterized those systems as "channeling" sentencer discretion on the deci-

In 1993, the Court retreated from its strict enforcement of the Lockett rule, at least for offenders convicted under the old Texas statute. Although, in 1989, the Court had struck down the Texas statute as applied to a mentally retarded offender with a history of abuse, see supra note $\mathbf{5 0}$ and accompanying text, the Court upheld the statute as applied to two youthful offenders, one of whom also had a history of abuse. See Johnson v. Texas, 509 U.S. 350, 368 (1993) ("We decide that there is no reasonable likelihood that the jury would have found itself foreclosed from considering the relevant aspects of petitioner's youth."); Graham v. Collins, 506 U.S. 461, 475 (1993) ("In this case... Graham's mitigating evidence was not placed beyond the jury's effective reach."). In each case, the offender contended that the evidence bore on his reduced culpability and pointed out that the statute did not ask a question that effectively allowed the jury to consider the evidence for what it informed about culpability. A five-Justice majority in each case, however, concluded that the jurors would understand that they should consider the evidence under the second question, regarding future dangerousness, for what it revealed about offender culpability. See Johnsom, 509 U.S. at 368 ("We believe that there is ample room in the assessment of future dangerousness for a juror to take account of the difficulties of youth as a mitigating force in the sentencing determinations."); Graham, 506 U.S. at 475 ("The jury was not forbidden to accept the suggestion of Graham's lawyers that his brief spasm of criminal activity in May 1981 was properly viewed, in light of his youth, his background, and his character, as an aberration that was not likely to be repeated."). This conclusion was justifiably criticized. See, e.g., id. at 519 (Souter, J., dissenting) (" $[A]$ sufficiently young defendant may have his continuing youth considered under the second issue as aggravating, not mitigating.").

${ }^{52}$ For a recent summary of capital-sentencing systems, focusing on the tendency of statutes to exclude persons from eligibility for the death penalty in ways that are not required by Supreme Court doctrine, see McCord, supra note 11, at 561-67.

${ }^{53}$ See Proffitt v. Florida 428 U.S. 242 (1976); Gregg v. Georgia, 428 U.S. 153 (1976). 
sion between imprisonment and death, ${ }^{54}$ the Court later clarified that a sentencing system need only "narrow" the group of offenders subject to discretionary decisionmaking. ${ }^{55}$ The Court also retracted its suggestion from 1976 that the Georgia system was acceptable because of the anticipated review for consistency to be provided by the Georgia appellate court. ${ }^{56}$ The Supreme Court declared that the narrowing function involved in the identification of an aggravating factor was all that the Eighth Amendment required as an adjunct to the broad, individualized inquiry. ${ }^{57}$

In the final analysis, then, the Court's Eighth Amendment regulation of capital-sentencing trials reduces to two mandates. First, a capital-sentencing system must allow for the presentation of a broad swath of mitigating evidence by the offender and the exercise of discretion by the sentencer. This individualization requirement calls

${ }^{34}$ See, e.g., Gregg, 428 U.S. at 206 (plurality opinion) (contending that, under the Georgia system, "the jury's discretion is channeled").

${ }^{35}$ In Zant $v$. Stephens, 462 U.S. 862 (1983), the Court declared that it had upheld the Georgia system "even though it clearly did not channel the jury's discretion." Id. at 875. The Court clarified in Zant that an aggravating circumstance need only "genuinely narrow the class of persons eligible for the death penalty and ... reasonably justify the imposition of a more severe sentence on the defendant compared to others found guilty of murder." Id. at 877.

${ }_{56}$ A few years after the decisions in the 1976 cases, Professor George Dix argued that the Georgia Supreme Court was not meaningfully carrying out the mandate to ensure consistency in the disposition of capital cases in Georgia. See George E. Dix, Appellate Review of the Decision to Impose Death, 68 GEO. L.J. 97, 119 (1979) ("The Georgia statute on its face does not limit mitigating evidence. But the Georgia court has been inconsistent in determining the kinds of evidence admissible in mitigation."). The Supreme Court could have reassessed the Georgia system in light of that failure. Instead, in Pulley v. Harris, 465 U.S. 37 (1984), the Court abandoned the suggestion that state appellate review to ensure consistency was required. The Harris decision concerned the absence of appellate consistency review in the California system. Although the Court asserted that consistency review might be required if a system lacked alternative protections against arbitrariness, the California scheme was the same in all significant respects as the Georgia system which the Court had approved in Gregg. See id. at 51. Therefore, after Harris, it became clear that the Georgia system would not be invalidated even if the Georgia Supreme Court altogether abandoned the purported practice of conducting a consistency review.

${ }^{57}$ See Lowenfield v. Phelps, 484 U.S. 231, 244 (1988) ("In Zant v. Stephens, we upheld a sentence of death imposed pursuant to the Georgia capital sentencing statute, under which 'the finding of an aggravating circumstance does not play any role in guiding the sentencing body in the exercise of its discretion, apart from its function of narrowing the class of persons convicted of murder who are eligible for the death penalty.' We found no constitutional deficiency in that scheme because the aggravating circumstances did all that the Constitution requires." (citation omitted) (quoting Zant, 462 U.S. at 874)). 
for an expansive inquiry and almost unfettered sentencer choice. ${ }^{58}$ Second, a capital-sentencing scheme must slightly narrow the class of persons eligible for the death penalty. This narrowing can be accomplished through a requirement that a factfinder identify an aggravating circumstance either at the guilt-or-innocence trial or at the sentencing hearing. ${ }^{59}$ If a capital-sentencing system embodies these two requirements, it is deemed to provide the "reasonable consistency" necessary to satisfy the concerns noted by the three crucial Justices in Furman. ${ }^{60}$

\section{THE FAIlURE OF "CONSISTENCY” AS A REgULATORY THEORY}

While the Court has typically advanced a "nonarbitrariness" or "consistency" rationale as the basis for regulating capital-sentencing trials, this rationale has failed in two related respects. First, the Court's doctrine has done relatively little to reduce the arbitrariness that characterizes the distribution of death penalties. This is a problem of fit between doctrine and aspiration; the rules that the Court

58 The evidentiary inquiry is not entirely unbounded, and sentencer choice can be limited in some minor respects. Some evidence that a party might wish to offer can be excluded because it does not relate to the defendant's character, record, or crime. See, e.g., Robison v. Maynard, 943 F.2d 1216, 1217 (10th Cir. 1987) (upholding exclusion of testimony by family members of the victim that they did not believe in the death penalty); Johnson v. Thigpen, 806 F.2d 1243, 1249-50 (5th Cir. 1986) (holding argument by counsel concerning execution procedure improper because evidence about execution procedure would be inadmissible). A state can also, for example, tell sentencers that they must vote for the death penalty if they find an aggravating circumstance but can identify nothing they believe to be a mitigating circumstance. See Blystone v. Pennsylvania, 494 U.S. 299, 305 (1990) (upholding such a state statute because "death is not automatically imposed" and "is imposed only after a determination that the aggravating circumstances outweigh the mitigating circumstances... or that there are no such mitigating circumstances"). A state can also tell sentencers, for example, that they must impose the death penalty if they find that any mitigating circumstances that they identify are outweighed in their view by the aggravating circumstances that they identify. See Boyde v. California, 494 U.S. 370, 377 (1990) (upholding the state statute, based on the reasoning of Blystone, "because the mandatory language . ... is not alleged to have interfered with the consideration of mitigating evidence"). Similarly, a state can tell sentencers, for example, not to act on "mere sentiment, conjecture, sympathy, passion, prejudice, public opinion or public feeling." California v. Brown, 479 U.S. 538, 542 (1987).

${ }^{59}$ See Lowenfield, 484 U.S. at 24445 ("We see no reason why this narrowing function may not be performed by jury findings at either the sentencing phase of the trial or the guilt phase.").

${ }^{60}$ See id. at 246 ("There is no question but that the Louisiana scheme narrows the class of death-eligible murderers and then at the sentencing phase allows for the consideration of mitigating circumstances and the exercise of discretion. The Constitution requires no more."). 
has produced do not achieve the goal that the Court has articulated. Second, the "nonarbitrariness" or "consistency" rationale lacks a grounding in the Eighth Amendment. This is a problem of fit between aspiration and the Constitution; nonarbitrariness or consistency in the treatment of capital offenders is not a goal that plausibly derives from a prohibition on "cruel and unusual punishments."

\section{A. The Divergence of the Court's Doctrine from the Consistency Theory}

The most common criticism of the Court's capital-sentencing doctrine has been that it does not produce consistent results. ${ }^{61}$ The doctrine, under this view, does not conform to the Court's stated purpose in regulating capital sentencing. This complaint is wellfounded. The Court's capital-sentencing decisions accomplish little in the way of ensuring that those who are convicted of capital offenses are sentenced according to a cognizable standard.

\section{Inconsistency Among Potentially Guilty Capital Offenders}

When considered against a consistency goal, the Court's capitalsentencing doctrine is problematic because the doctrine applies at only one of several stages where the choice between death and imprisonment occurs. A person who is factually guilty of a capital offense may be spared from the death penalty at the charging stage because she is charged with a noncapital offense. She may be spared at the pretrial stage through a plea agreement that insulates her from the capital punishment. ${ }^{62}$ The capital offender may also be spared at the guilt-or-innocence stage of the trial if the trier of fact acquits her on the capital charge despite her factual guilt. ${ }^{63}$ She may be spared in some jurisdictions by the prosecutor's decision after conviction not to pursue the death sentence. ${ }^{64}$ Finally, the defendant who receives the

61 See supra note 4 and accompanying text.

62 Regarding the extent to which plea-bargaining occurs in capital cases, see WELSH S. WHITE, THE DEATH PENALTY IN THE NINETIES 53-70 (1991).

${ }^{63}$ Jurors in criminal cases may validly acquit a defendant who appears guilty, although they are not informed of this "nullification" power. See generally Alan Scheflin \& Jon Van Dyke, Jury Nullification: The Contours of a Controversy, LAw \& CONTEMP. PROBS., Autumn 1980, at 51, $52-56$ (discussing jury nullification in criminal trials).

${ }^{64}$ Prosecutors have exercised this power frequently, for example, in the postFurman Georgia system. See DAVD C. BALDUS ET AL., EQUAL JUSTICE AND THE DEATH PENALTY 106 (1990) [hereinafter BALDUS STUDY] ("[I]n 59 percent of the death 
death penalty may be spared through clemency or pardon. ${ }^{65}$ Substantial discretion lies with the decisionmaker at each of these stages. Given the many opportunities for arbitrary action, the distribution of death sentences among those who have committed capital offenses would not likely align in a tolerable pattern merely through regulation of the sentencing trial. ${ }^{66}$

The Court's decisions are not sensibly understood, moreover, as indicating that persons convicted of capital offenses constitute the group within which to pursue consistency. The Court has sometimes suggested that potential arbitrariness among this narrow class is its concern. ${ }^{67}$ However, only if regulation of the sentencing trial influenced the exercise of discretion at other stages could such a circumscribed focus make sense. The only reason to limit discretion at the sentencing stage is to control arbitrariness in the overall selection of a group to be exterminated. ${ }^{68}$ Indeed, if arbitrary decisions to spare capital offenders occur throughout the remainder of the selection process, circumscribing sentencer discretion will do little, if anything, to promote consistency in the distribution of death sentences.

eligible cases, a life sentence was imposed by default when the prosecutor unilaterally waived the penalty trial.").

${ }^{65}$ Regarding the lack of standards governing clemency decisions, see Elkan Abramowitz \& David Paget, Note, Executive Clemency in Capital Cases, 39 N.Y.U. L. REv. 136 (1964).

${ }_{66}^{6}$ This point was made in an important article on capital punishment published shortly before the Supreme Court's Furman decision. See Arthur J. Goldberg \& Alan M. Dershowitz, Declaring the Death Penalty Unconstitutional, 83 HARV. L. REV. 1773, 1793 (1970) ("[I]t is very unlikely that essentially arbitrary and discriminatory impositions of capital punishment can be halted... Prosecutorial discretion at one end of the process and executive clemency discretion at the other may be enough to preserve the capricious character of capital punishment.").

${ }^{67}$ See, e.g., Gregg v. Georgia, 428 U.S. 153, 200 (1976) (plurality opinion) (asserting that the Furman mandate was only concerned with discretion at the capitalsentencing stage).

${ }^{63}$ The plurality's opinion striking down the mandatory death statute in Woodson $v$. North Carolina, 428 U.S. 280 (1976), makes this point. The plurality asserted that mandatory death-penalty statutes will likely only cause jurors at the guilt-or-innocence stage to arbitrarily acquit some guilty capital offenders out of a belief that the death penalty is an inappropriate sanction in the case. See id. at 302-03 (plurality opinion) (referring to a state study which found that "juries in the State '[q]uite frequently' were deterred from rendering guilty verdicts of first-degree murder because of the enormity of the sentence automatically imposed" and concluding that "it is only reasonable to assume that many juries under mandatory statutes will continue to consider the grave consequences of a conviction in reaching a verdict" (alteration in original)). This contention assumes that the group within which to assess whether death sentences are distributed consistently is greater than merely those who have been convicted of the capital offense. 
The Court's regulation of the sentencing stage, however, could not plausibly be thought to limit arbitrariness at other stages of the selection process. The Court has sometimes suggested that the strength of evidence on guilt and the applicability of sentencing criteria favoring death will largely control the prosecutor's decisions at the charging and plea-bargaining stages and the decision whether to pursue the death penalty after conviction. ${ }^{69}$ Empirical evidence, however, has demonstrated the fallacy of this argument. Professor Welsh White concludes, based on empirical evidence, that pleabargaining in capital cases is not controlled or even heavily influenced by whether a death sentence could be secured. ${ }^{70}$ Citing the importance of various matters influencing prosecutors, such as local custom, economic considerations, political concerns, and the quality of defense counsel, Professor White concludes that "the likelihood of a plea bargain in a capital case will be dramatically affected by factors that have nothing to do with the nature of the crime or the strength of the evidence against the defendant."

Further, a well-known study of the Georgia system in the mid1980 s, headed by Professor David Baldus (the "Baldus study"), determined that most capital offenders in Georgia were spared from execution at stages other than the sentencing trial, even though the sentencing standards were so expansive as to cover almost all capital offenses. ${ }^{72}$ Most significantly, the researchers found that, even after winning conviction on a capital offense, the prosecutor elected not to pursue the death penalty in approximately two-thirds of the cases. ${ }^{73}$ Hence, the notion that officials with discretion to reprieve offenders

${ }^{69}$ For example, Justice White contended in his opinion in Gregg that insufficient evidence existed to conclude that prosecutors would base their charging and pleabargaining decisions on considerations other than whether the factfinder and sentencer would return a guilty verdict and a death sentence. See 428 U.S. at 225-26 (White, J., concurring in judgment).

${ }^{70}$ See WHITE, supra note 62, at 54-62 (examining prosecutorial use of pleabargaining).

71 Id. at 54.

72 See BALDUS STUDY, supra note 64, at 233-34 (describing the exemption of capital offenders due to plea-bargaining and post-conviction decisions by prosecutors not to pursue the death penalty); id. at $268 \mathrm{n} .31$ (noting that between 1974 and $1979,65 \%$ of defendants convicted of murder or voluntary manslaughter were eligible for the death penalty); id. at $88-89$ (noting an overall death-sentencing rate of $23 \%$ of all deatheligible defendants between 1973 and 1978).

73 See id. at 327 tbl.56 (noting the percentages of cases in which prosecutors sought death sentences based on the race of defendants and victims). 
outside of the sentencing hearing will follow standards applicable at the sentencing stage is untenable. ${ }^{74}$

The Court's capital-sentencing regulation diverges from the consistency rationale that the Court has offered to justify the doctrine. A capital-sentencing system that only imposes decisional standards at the sentencing phase does little to ensure the consistent distribution of death sentences among all who are factually guilty of capital murder. Yet, the Court's doctrine does not seem logically addressed to promote consistency even in the decisions reached at the capitalsentencing hearing.

\section{Inconsistency Among Convicted Capital Offenders}

The Eighth Amendment restrictions the Court has imposed on capital-sentencing trials have essentially reproduced the pre-Furman world of capital sentencing. ${ }^{75}$ We have already seen that the two principal mandates embodied in the Court's modern decisions are the narrowing requirement and the requirement of individualized sentencing. ${ }^{76}$ Neither of these mandates, as they have been implemented by the Court, would seem to reduce arbitrariness in the distribution of capital punishment among those convicted of capital offenses. As two prominent scholars of the Court's capital-sentencing decisions have concluded, the Court has "promot[ed] the appearance of intensive regulation despite its virtual absence."77

${ }^{74}$ Standards imposed to restrict sentencer discretion to reprieve capital offenders would seem most likely to cause officials operating at other stages to increase their use of discretion. This view was articulated shortly after the Furman decision:

[I]mpulses [to reprieve capital offenders at nonsentencing phases] all become stronger in a system in which discretion in the sentencing stage has been confined. Defendants will be less willing to plead guilty to a count when a statute makes the imposition of death probable or mandatory, and thus plea bargaining will usually require reducing the charge. More important, the impulse to individualize treatment in nonsentencing stages becomes particularly powerful when a major source of flexibility elsewhere in the criminal process has been confined. Prosecutors, knowing that obtaining a capital conviction will likely result in a death sentence, will be more inclined to reduce charges, and pardoners may review more carefully sentences which were imposed without any opportunity for the sentencer to be lenient.

Note, supra note 19, at 1715-16 (footnotes omitted).

${ }^{75}$ See, e.g., Steiker \& Steiker, supra note 3, at 359 (“[T] odd years of doctrinal head-banging has been to substantially reproduce the preFurman world of capital sentencing.").

${ }^{76}$ See supra Part I.B-C.

${ }^{77}$ Steiker \& Steiker, supra note 3, at 438. 


\section{a. The Narrowing Requirement}

The Court's narrowing requirement, even if it amounted to a mandate to reduce substantially the group subject to the death penalty, would not logically reduce the arbitrary treatment of convicted capital offenders. A substantial narrowing of those eligible for the death penalty reduces the number of persons subject to a discretionary decision to impose the death penalty. However, a narrowing of the death-eligible group may also increase the number of unfounded exemptions from the death penalty. Indeed, the number of persons who warrant the death penalty but who are exempted from it through a narrowing process could exceed the number of persons who do not warrant the death penalty and are saved from it. Is this result preferable? Unfounded exemptions from the death penalty are as problematic as unfounded impositions of that sanction if the Eighth Amendment mandates consistency. ${ }^{78}$ On this view, the reduction in the size of the group eligible for death does not necessarily improve the distribution of death penalties. ${ }^{79}$

On the functional level, the Court's narrowing mandate also fails to require states to reduce significantly the group eligible for death. The Court has examined single aggravating circumstances and at times has concluded that they are invalid because they could reasonably be thought to describe all capital offenders. ${ }^{80}$ However, the Court has never required that a capital-sentencing scheme, consid-

${ }^{78}$ The Court has not suggested that there is a standard by which to assess when a death sentence is or is not warranted. Nonetheless, this further failing on the Court's part only casts doubt on the notion that consistency is the goal. The notion that the aim is a type of consistency other than the same sentence for all capital offenders implies that there is a measure for determining when a death sentence is warranted.

${ }^{79}$ See Ronald J. Allen, Foreword-Evidence, Inference, Rules, and Judgment in Constitutional Adjudication: The Intriguing Case of Walton v. Arizona, 81 J. CRIM. L. \& CRIMINOLOGY 727, 736-37 (1991) (concluding that although the absolute quantity of "arbitrary" death sentences in a state could decrease, the number of "arbitrary" imprisonment sentences could increase so that the proportion of "arbitrary" sentencing decisions could remain unchanged).

${ }^{80}$ See Maynard v. Cartwright, 486 U.S. 356, 363-65 (1988) (invalidating a mandatory death sentence imposed based on a statutory aggravating circumstance that the murder was "especially heinous, atrocious, or cruel" as overbroad and vague (quoting OKLA. STAT. ANN. tit. 21, § 701.12(4) (West 1981))); Godfrey v. Georgia, 446 U.S. 420, 432-33 (1980) (plurality opinion) (invalidating a mandatory death sentence imposed based on a sweeping statutory aggravating circumstance because the state's highest court failed to limit its breadth); id. at 434-35 (Marshall, J., concurring in judgment) (disapproving aggravating circumstance that the murder was "outrageously or wantonly vile, horrible or inhuman in that it involved torture, depravity of mind, or an aggravated battery to the victim'” (quoting GA. CODE ANN. \$27-2534.1(b)(7) (1978))). 
ered as a whole, significantly reduce the group eligible for the death penalty. First, the Court has never clarified the starting point from which the reduction must occur. The Court has spoken at times of murder as the starting point, ${ }^{81}$ but some murders are per se excluded from death eligibility, ${ }^{82}$ and excluding them through the narrowing process would not amount to additional narrowing. ${ }^{83}$ More importantly, the Court has failed to demand that a state's aggravating circumstances, considered together, significantly reduce the group eligible for the death penalty. The narrowing restrictions, as applied by the Court, are merely rules against vagueness applied to individual aggravators rather than rules regarding the extent of narrowing required of systems considered as whole entities. A state could, for example, specify more than a dozen aggravating circumstances that might together cover virtually all capital murders, but nonetheless satisfy the Court's narrowing restrictions. ${ }^{84}$ Even regarding individual aggravators, the Court has not demanded significant narrowing or narrowing with any substantive measure in mind. An individual aggravator is valid even though it covers a huge category of murders. ${ }^{85}$ Thus, despite rhetoric suggesting a forceful narrowing command, ${ }^{86}$ the Court

${ }^{81}$ See, e.g., Zant v. Stephens, 462 U.S. 862, 874 (1983) (noting that the finding of an aggravating circumstance serves to "narrow[] the class of persons convicted of murder who are eligible for the death penalty").

${ }^{82}$ In Enmund v. Florida, 458 U.S. 782 (1982), the Supreme Court concluded that the death penalty was per se unconstitutional even for murder, absent a finding that the defendant intended to or attempted to kill, or actually killed a human being. See id. at 797-98. In Tison v. Arizona, 481 U.S. 137 (1987), the Court reduced the group of murders that were per se exempted from the capital punishment. The Court concluded that the death penalty was permissible for one who did not intend to or attempt to kill, or actually kill, if the prosecution could establish "major participation in the felony committed, combined with reckless indifference to human life." Id. at 158.

${ }^{8 s}$ The Court also at times has implied that the starting point is the group that is not per se excluded from the death penalty, which is not the same category as those who have been convicted of murder. See, e.g., Lowenfield v. Phelps, 484 U.S. 231, 244 (1988) ("To pass constitutional muster, a capital sentencing scheme must 'genuinely narrow the class of persons eligible for the death penalty ...'" (quoting Zant, 462 U.S. at 877)).

${ }^{84}$ For example, the relevant statute currently in force in California specifies 21 "special circumstances" that, together, cover the vast majority of capital murders. See CAL. PENAL CODE $\S 190.2$ (West Supp. 1997).

${ }^{85}$ It is common for states to specify as an aggravating factor that the murder was committed while the defendant was engaged in, or an accomplice in, or attempting to commit a variety of felonies. See, e.g., id. \$190.2(a)(17) (listing twelve felonies).

${ }^{86}$ In Zant, the Court declared that a capital-sentencing scheme must "genuinely narrow the class of persons eligible for the death penalty and must reasonably justify the imposition of a more severe sentence on the defendant compared to others found guilty of murder." 462 U.S. at 877. 
has never demanded through the narrowing mandate that capitalsentencing systems substantially circumscribe the group subject to execution.

Indeed, states have not understood the Court's command against vague aggravators as requiring that their systems substantially narrow the death-eligible group or that they pursue any particular theory for deciding who dies. In Georgia, for example, the state legislature set out a list of ten aggravating circumstances in its post-Furman statute. ${ }^{88}$ Some of the aggravators were subsequently struck down as being too vague. ${ }^{89}$ Nonetheless, the Baldus study, which was performed in the mid-1980s, determined that ninety percent of the pre-Furman Georgia cases in which the death penalty was imposed would still fall under at least one of the valid aggravating circumstances included in the new sentencing scheme..$^{90}$ Hence, the combination of aggravating circumstances has not greatly reduced the number of persons subject to a possible death sentence. Further, the murderers who are spared by the narrowing process are hardly all persons who appear to warrant an exemption. A sniper who stalks and kills her victim for revenge with a high-powered rifle would not qualify for the death penalty. However, a person who contracts for such a killing, ${ }^{91}$ or who kills the

${ }^{87}$ As for the antivagueness command regarding individual aggravators, the Court has also shown reluctance in recent years to invalidate rather vague aggravators. See Arave v. Creech, 507 U.S. 463, 467-68 (1993) (approving an aggravating circumstance requiring a finding that "[b]y the murder, or circumstances surrounding its commission, the defendant exhibited utter disregard for human life" because of narrowing construction by state court requiring a finding that the defendant was a "cold-blooded, pitiless slayer"). For criticism of the Court's decision in Creech, see Susan RaekerJordan, A Pro-Death, Self-Fulfilling Constitutional Construct: The Supreme Court's Evolving Standard of Decency for the Death Penalty, 23 HASTINGS CONST. L.Q. 455, 535 (1996) ("[T]he majority erred in refusing to admit that the term 'cold-blooded' can be applied to many cases that fit outside the definition constructed by the majority.").

${ }^{8}$ See GA. CODE ANN. § 27-2534.1 (Supp. 1975), quoted in Gregg v. Georgia, 428 U.S. 153, $165 \mathrm{n} .9$ (1976) (plurality opinion).

${ }^{89}$ See Godfrey v. Georgia, 446 U.S. 420, 432-33 (1980) (plurality opinion) (noting that descriptive factors such as "outrageously or wantonly vile" and "horrible or inhuman" were insufficiently definite to sustain the requirement that a death sentence be based on "reason rather than caprice or emotion"); id at 434-35 (Marshall, J., concurring in judgment) (disapproving an aggravating circumstance that required the jury to find that the murder was "outrageously or wantonly vile, horrible or inhuman in that it involved torture, depravity of mind, or an aggravated battery to the victim" (quoting GA. CODE. ANN. \$ 27-2534.1(b)(7) (1978))); Arnold v. State, 224 S.E.2d 386, $391-92$ (Ga. 1976) (invalidating an aggravating circumstance requiring that jury find "a substantial history of seriously assaultive criminal convictions").

See BALdUS STUdY, supra note 64, at 102.

9 See GA. CODE ANN. $\$ 17-10-30$ (b) (6) (1997) (defining as an aggravating circumstance that "the offender caused or directed another to commit murder"). 
same victim for money, ${ }^{92}$ would face possible execution. Why should these distinctions matter? Further, Georgia, like many other states, uses felony murder as a narrowing device. ${ }^{93}$ Some felony murderers are highly dangerous. However, the felony-murder class includes "not only cold-blooded killers but accidental killers and attenuated accomplices," ${ }^{94}$ hardly the worst murderers. Hence, it appears that the Georgia aggravators provide a far too limited and haphazard system of narrowing to reduce substantially the inconsistency of death sentences compared to those resulting when jurors are not required to find an aggravator. ${ }^{95}$

\section{b. The Requirement of Individualized Sentencing}

The Court's command that states allow for the rejection of the death penalty based on a consideration of a broad array of perceived mitigating circumstances ${ }^{96}$ also would not logically promote consistency in the distribution of death penalties. The argument in favor of the broad individualization mandate is that sentencers have the opportunity to consider much more information about the offender than under the typical pre-Furman system and that this additional information will lead them to make better judgments. ${ }^{97}$ However, the absence of any standards to guide jurors in the use of the sentencing evidence evokes doubt that the results would align with some acceptable measure. Sentencers are not even told what question they are supposed to answer when they consider the alleged mitigating and aggravating evidence. Are sentencers to ask whether the defendant deserves the death penalty? If so, should they consider only the defendant's culpability for the murder or, instead, the defendant's

${ }^{92}$ See id. $\S 17-10-30(\mathrm{~b})(4)$ (defining as an aggravating circumstance that " $[\mathrm{t}] \mathrm{he}$ offender committed the offense of murder for himself or another, for the purpose of receiving money").

${ }^{93}$ See id. $\$ 17-10-30$ (b)(2) (defining as an aggravating circumstance that the murder occurred during the commission of certain other felonies).

${ }^{94}$ Richard A. Rosen, Felony Murder and the Eighth Amendment Jurisprudence of Death, 31 B.C. L. REV. 1103, 1129 (1990).

${ }^{95}$ For a more favorable view of the narrowing impact of Georgia's statutory aggravators, building on the view that the Court was much more concerned with overinclusion than underinclusion in the death-eligible group, see McCord, supra note 11, at 577.

${ }^{96}$ For a discussion of the Court's broad individualization mandate, see supra notes 32-51 and accompanying text.

${ }^{97}$ See McCord, supra note 11, at 577-78. 
"general deserts" or "moral merit" Alternatively, perhaps sentencers should ask a utilitarian question, such as whether the defendant poses a future danger if not executed. Yet, even if sentencers miraculously agreed across cases on what general question to ask, they likely would not concur on the answer to be given in particular cases. The answers given after the broad, individualized inquiry may well turn as much on the values of the sentencers involved as on the evidence presented. ${ }^{100}$

The view that the broad individualization mandate conflicts with the consistency command has been widespread among commentators $^{101}$ and the Justices themselves. ${ }^{102}$ On this view, as the number of

${ }^{s s}$ I coined these terms in an earlier article to describe a broad deserts inquiry which the Court's decisions in Lockett and its progeny arguably allow. See Scott W. Howe, Resolving the Conflict in the Capital Sentencing Cases: A Desert-Oriented Theory of Regulation, 26 GA. L. REv. 323, 351 (1992) (explaining that the terms "moral merit" and "general deserts" refer to an inquiry into "the offender's deserts based on all aspects of his life").

"The broader, "general deserts" assessment incorporates an assessment of the offender's "culpability" for the capital crime. See Carol S. Steiker \& Jordan M. Steiker, Let God Sort Them Out? Refining the Individualization Requirement in Capital Sentencing, 102 YALE L.J. 835, 847 (1992) (reviewing BeVERLY LOWRY, CROSSEd OVER (1992)) ('Evidence of positive character traits and past good works may reveal a defendant's 'general desert[s]' and contribute to a moral assessment of the defendant's entire life that includes, but is not limited to, the defendant's culpability for the crime.").

${ }^{100}$ See infra note 134 and accompanying text.

101 See, e.g., Garvey, supra note 39, at 1001 ("Commentators have often remarked that Furman's mandate of consistency and Woodson's mandate of individualization compete with one another at some level.").

${ }^{102}$ See Tuilaepa v. California, 512 U.S. 967, $972-73$ (1994) (noting that the objectives of the selection decision and eligibility decision "can be in some tension" when the inquiries occur at the same time); Romano v. Oklahoma, 512 U.S. 1, 6-7 (1994) (explaining that states have been required to perform "two somewhat contradictory tasks" in order to impose the death penalty); Callins v. Collins, 510 U.S. 1141, 1141-42 (1994) (Scalia, J., concurring in denial of certiorari) ("[T]he Court has attached to the imposition of the death penalty two quite incompatible sets of demands: The sentencer's discretion to impose death must be closely confined, but the sentencer's discretion not to impose death (to extend mercy) must be unlimited." (citations omitted)); Graham v. Collins, 506 U.S. 461, 479 (1993) (Thomas, J., concurring) (noting the tension between the Court's decisions which both require consideration of mitigating circumstances and prohibit allowing sentencers unguided discretion in imposing the death penalty); Walton v. Arizona, 497 U.S. 639, 673 (1990) (Scalia, J., concurring in part and concurring in judgment) (explaining that the constitutional objective enunciated in Furman cannot be achieved simultaneously with the constitutional objective enunciated in Woodson and Lockett); Franklin v. Lynaugh, 487 U.S. 164, 181-82 (1988) (plurality opinion) (noting that two lines of cases, one suggesting unlimited discretion and the other requiring limits on discretion, are in tension with each other); California v. Brown, 479 U.S. 538, 544 (1987) (O'Connor, J., concurring) ("This case squarely presents the tension that has long existed between the two central 
factors deemed potentially relevant at the sentencing inquiry grows, the potential for consistency according to an identifiable measure declines. Conversely, as the effort to achieve consistency is pursued, either through death penalties mandatory upon conviction or through channeling sentencing standards, the sentencer's freedom to consider mitigating and aggravating evidence will shrink. Nonetheless, the Court has concluded that the Eighth Amendment mandates broad individualization, even in cases where the defendant is convicted of a murder with highly aggravating circumstances. ${ }^{103}$

\section{c. Empirical Studies}

The Court also has been impervious to challenges to its capitalsentencing doctrine based on studies of post-Furman sentencing schemes indicating that substantial arbitrariness remains. ${ }^{104}$ The Baldus study, which was used in litigation before the Court, ${ }^{105}$ focused on the Georgia system in the decade after the Court first sanctioned the resumption of capital punishment. ${ }^{106}$ The Baldus study demonstrated continuing arbitrariness in the distribution of death sentences and, in particular, racial discrimination based predominantly on the

principles of our Eighth Amendment jurisprudence."); Lockett v. Ohio, 438 U.S. 586, 622 (1978) (White, J., dissenting in part) (describing the plurality's holding that "the sentencer may constitutionally impose the death penalty only as an exercise of his unguided discretion after being presented with all circumstances which the defendant might believe to be conceivably relevant" as a complete "about-face" from Furman's command against arbitrariness); $i d$. at 631 (Rehnquist, J., dissenting in part) ("If a defendant as a matter of constitutional law is to be permitted to offer as evidence in the sentencing hearing any fact, however bizarre, which he wishes, even though the most sympathetically disposed trial judge could conceive of no basis upon which the jury might take it into account in imposing a sentence, the new constitutional doctrine will not eliminate arbitrariness or freakishness in the imposition of sentences, but will codify and institutionalize it.").

${ }^{103}$ See, e.g., Sumner v. Shuman, 483 U.S. 66, 85 (1987) (invalidating a statute requiring mandatory death penalty for life-term inmates who commit murder); Roberts v. Louisiana, 431 U.S. 633, 637-38 (1977) (per curiam) (striking down the death penalty imposed pursuant to the mandatory death-penalty statute on the murderer of a police officer).

${ }^{104}$ Numerous studies from many states reveal a pattern of sentencing in capital cases influenced heavily by the race of the victim. See Ronald J. Tabak, Is Racism Irrelevant? Or Should the Fairness in Death Sentencing Act Be Enacted to Substantially Diminish Racial Discrimination in Capital Sentencing?, 18 REV. LAW \& SOC. CHANGE 777, 780-83 (1991) (noting a national pattern of discrimination in capital sentencing based on the race of the victim).

${ }^{105}$ See infra notes 113-19 and accompanying text.

${ }^{106}$ See generally BALDUS STUDY, supra note 64. 
race of the victim. ${ }^{107}$ The researchers found, initially, that a convicted murderer of a white victim was much more likely to receive the death penalty than a convicted murderer of a black victim. ${ }^{108}$ Professor

107 The Baldus researchers conducted two studies of the capital-sentencing system in Georgia. Their original study, dubbed the Procedural Reform Study (the "PRS"), aimed to test for arbitrariness in both pre- and post-Furman cases at two stages of the death selection process-the decision of the prosecutor whether to pursue death after conviction and the sentencing decision of the jury. See id at 42 . This effort was problematic in that it was unclear how to judge whether a sentencing decision was arbitrary as opposed to appropriate; the Supreme Court has never provided consistent direction even as to the basic nature of the judgment to be rendered by a capital sentencer. In deciding when sentencing results were arbitrary as opposed to acceptable, the researchers, therefore, were required to rely heavily on their own values as to how capital-murder cases should be judged. See id. at 84 (explaining evidence of excessiveness in terms of what the researchers considered excessive or evenhanded). The conclusions of the PRS were subject to challenges based on the subjectivity of judgments underlying them. See, e.g., Randall L. Kennedy, McCleskey v. Kemp: Race, Capital Punishment and the Supreme Court, 101 HARV. L. REV. 1388, 1432-33 (1988) (disagreeing with the Baldus researchers' assessment of propriety of the death penalty in McCleskey, discussed infra notes 113-20 and accompanying text).

After completing the PRS, the researchers decided to conduct a second study, dubbed the Charging and Sentencing Study (the "CSS"), which focused mainly on how racial discrimination influenced the flow of cases from indictment to sentencing. See BALDUS STUDY, supra note 64, at 45. The idea of "arbitrariness," which was the focus of the PRS study, was difficult to pin down and, therefore, difficult to measure. The notion of "discrimination" based on race, however, connoted a clearer problem. Through the use of regression analysis, employed after detailing scores of characteristics of all cases in the study, the researchers could make relatively persuasive conclusions about the influence of racial factors on outcomes. The CSS also measured for racial discrimination from the point of indictment all the way to the jury's sentencing decision. See id. at 45-46.

${ }^{103}$ For all persons charged with murder in Georgia between 1973 and 1979, the Baldus researchers found the following death-sentencing rates in comparing categories accounting for the race of the defendant and victim:
Race of Defendant \& Victim
1. black defendant/white victim
2. white defendant/white victim
3. black defendant/black victim
4. white defendant/black victim
TOTAL

Death Sentencing Rates $.21(50 / 233)$ $.01(18 / 1443)$

$.05(128 / 2484)$

See Baldus STUDY, supra note 64, at 315 tbl.50.

Note that the race of the victim correlates with death sentencing rates more than the race of the defendant does. The death sentencing rates for cases involving white victims are much higher than the rates for cases involving black victims. Within the category of white victim cases, however, there is a large disparity in death sentencing rates corresponding to the race of the defendant. Within this category, black defendants receive death sentences at a much higher rate than white defendants.

While the possibility of hidden variables coincidentally corresponding to racial variables means that these results do not prove that race matters, the results may be persuasive to many observers. The possibility that acceptable, nonracial factors could 
Baldus and his colleagues employed sophisticated statistical analysis to determine if this outcome was explainable by factors other than race. However, after accounting for more than 200 nonracial variables that might have influenced the sentencing decisions, ${ }^{109}$ the researchers determined that the race of the victim continued to exert a powerful influence on the capital-sentencing decision. According to the study, because of the race of the victim, a convicted murderer of a white victim was 4.3 times more likely to receive the death penalty than a convicted murderer of a black victim. ${ }^{10}$ As for race-ofdefendant discrimination, the researchers found no overall discrimination against black defendants in the totality of post-Furman cases; ${ }^{11}$ however, within the white-victim cases, they determined that a black defendant was 2.4 times more likely to receive a death sentence than a white defendant because of the race-of-defendant factor. ${ }^{12}$

Lawyers used the Baldus study on behalf of a black inmate, Warren McCleskey, who had been sentenced to death in Georgia for murdering a white police officer. ${ }^{113}$ McCleskey's counsel argued that the Baldus study warranted invalidating his death sentence as violative of both equal protection and the Eighth Amendment. ${ }^{114}$ In a five-tofour decision, the Court rejected both claims. ${ }^{115}$ The equal-protection claim failed, the majority concluded, because McCleskey had not established with the Baldus evidence purposeful discrimination by his prosecutor or jury. ${ }^{116}$ The Eighth Amendment claim failed essentially because nonarbitrariness in the Eighth Amendment sense is pre-

explain the differences may appear doubtful. The Baldus researchers sought to identify any such hidden factors.

${ }^{109}$ Although the authors amassed data for approximately 230 characteristics, see id. at 46, and used one model that controlled for 230 variables, statistical analysis revealed that a 39-variable model best explained the sentencing patterns observed, see id. at 316 . The authors note that the problem of overlapping variables, causing the misstatement of the influence of certain variables, made the use of the model with fewer variables more appropriate. See id. at 457-58.

${ }^{110}$ See id. at 316.

111 See id. at 328.

112 See id.

${ }^{113}$ See McCleskey v. Kemp, 481 U.S. 279, 283 (1987).

114 See id. at 286.

${ }^{115}$ See id. at 299 (rejecting McCleskey's equal-protection claim); id. at 319 (holding that the statistics put forth by McCleskey did not establish violation of the Eighth Amendment). The majority consisted of Justice Powell, writing for the Court, Chief Justice Rehnquist, and Justices White, O'Connor, and Scalia. The dissenters were Justices Brennan, Marshall, Blackmun, and Stevens.

${ }^{116}$ See id. at 292 (stating that equal-protection violation requires proof "that the decisionmakers in his case acted with discriminatory purpose"). 
sumptively established, the majority declared, by a state's compliance with the Court's Eighth Amendment doctrine governing capital sentencing. ${ }^{117}$ In a troubling demand for certitude, ${ }^{118}$ the majority also declined to concede that the Baldus statistics established that the Georgia system produced results infested with improper racial influences. ${ }^{119}$ Of course, the majority was therefore unwilling to acknowledge that its regulation of capital sentencing had failed to produce an appropriate pattern separating convicted murderers who received the death penalty from those who were spared. ${ }^{120}$

In the final analysis, the Court's stated theory for regulating capital-sentencing trials has not heavily influenced the doctrine that it has produced. The Court has only required that the sentencer identify an aggravating circumstance before the defendant becomes deatheligible and that the sentencer subsequently have discretion to reject the death penalty based on information offered by the defendant about her character, record, and crime. These requirements cannot plausibly be thought to promote substantial consistency in the distribution of death sentences among all factually guilty capital offenders or even among those actually convicted of capital crimes. ${ }^{121}$

${ }^{117}$ The Court noted at one point:

Because McCleskey's sentence was imposed under Georgia sentencing procedures that focus discretion "on the particularized nature of the crime and the particularized characteristics of the individual defendant," we lawfully may presume that McCleskey's death sentence was not "wantonly and freakishly" imposed, and thus that the sentence is not disproportionate within any recognized meaning under the Eighth Amendment.

Id. at 308 (citations omitted) (quoting Gregg v. Georgia, 428 U.S. 153, 206-07 (1976) (plurality opinion)).

Although subsequently addressing McCleskey's claim that the Georgia capitalpunishment system was arbitrary and capricious in application, the majority essentially relied on the contention that the Baldus study did not "prove that race enters into any capital sentencing decisions or that race was a factor in McCleskey's particular case." Id. For further analysis of this portion of the majority's opinion, see RANDALL KENNEDY, RACE, CRIME, AND THE LAW 335-39 (1997).

${ }^{118}$ See Kennedy, supra note 107, at 1389 ("[T] he majority in McCleskey repressed the truth and validated racially oppressive official conduct ....").

119 See McCleskey, 481 U.S. at 312 ("At most, the Baldus study indicates a discrepancy that appears to correlate with race."); id. at 313 ("[W]e decline to assume that what is unexplained is invidious.").

${ }^{120}$ This was the aim of capital-sentencing regulation that the Court had repeated on more than one occasion. See supra note 25.

${ }^{122}$ Many commentators have previously reached this conclusion. See, e.g., Vivian Berger, "Black Box Decisions" on Life or Death-If They're Arbitrary, Don't Blame the Jury: A Reply to Judge Patrick Higginbotham, 41 CASE W. RES. L. REv. 1067, 1091 (1991) (noting that "actual holdings [from the Supreme Court] premised on the goal of avoiding arbitrary executions have become a form of endangered species"); Steiker \& Steiker, 


\section{B. The Divergence of Consistency Theory from Eighth Amendment Values}

If the Court's doctrine fails to promote substantial consistency in the use of the death penalty, we should ask whether the consistency mandate is grounded in the Eighth Amendment. In fact, the Eighth Amendment is not appropriately understood to require consistent use of the death penalty. The problems with imposing such a mandate under the Eighth Amendment help to clarify why the Court has not seriously pursued it.

A mandate of consistency assumes that the Eighth Amendment requires no particular substantive standard by which to separate those who receive the death penalty from those who are spared. This mandate assumes that there are many appropriate patterns for distributing death penalties. Thus, while a state could not use standards that violate other constitutional prohibitions, such as those against racial discrimination or inhibitions on free speech, states would retain wide authority under the Eighth Amendment to control the capital sentencer's exercise of discretion. Nonetheless, if the mandate is consistency, a capital-sentencing scheme should provide a "meaningful basis for distinguishing the few cases in which [the penalty] is imposed from the many cases in which it is not.",122

Interpretation of the Eighth Amendment to require consistency, however, is misguided. If the Eighth Amendment required consistency, a system involving unrelenting harshness in the imposition of death sentences should succeed, while a system giving officials discretion to extend merciful reprieves should fail. Following this reasoning, the protection against "cruel and unusual punishments," would require, or at least allow, mandatory death penalties. Courts also would need to regulate the decisions of prosecutors and other state officials at all stages of the death-selection process to ensure that they did not allow persons who were death eligible to escape the death penalty without good reason. If the function of the Eighth Amendment is to ensure consistency in the separation of those who receive the sanction from those who are spared, regulation should focus on all phases of the overall selection process. The aim is to ensure that

supra note 3, at $402-03$ (stating that "the fact of minimal regulation ... invites if not guarantees the same kinds of inequality as the pre-Furman regime").

${ }^{122}$ Godfrey v. Georgia, 446 U.S. 420, 427 (1980) (plurality opinion) (alteration in original) (quoting Furman v. Georgia, 408 U.S. 238, 313 (1972) (White, J., concurring)). 
all offenders who meet a certain standard receive the death penalty as much as it is to ensure that those who do not meet the standard are spared. On this view, many murderers, perhaps even all of them, should suffer execution; their execution, as opposed to a merciful exemption from death, would protect them from cruel and unusual punishment. The profound irony of this conclusion suggests the implausibility of the consistency theory as an appropriate Eighth Amendment principle. ${ }^{123}$

The consistency view of the Cruel and Unusual Punishments Clause lacks a foundation in history. The view finds no support in the pre-Furman holdings of the Supreme Court. Moreover, the view lacks support in the historical evidence surrounding the inclusion of the Clause in the Amendment. ${ }^{124}$ Although the purpose of the prohibition in the minds of the promulgators is uncertain, ${ }^{125}$ serious dispute has never encompassed the notion that the Clause was intended to mandate consistent treatment of offenders. The genuine debate has focused on whether the Clause was only intended to prohibit certain forms of punishment or whether it was also intended to prohibit punishments that, although sometimes permissible, are disproportionately severe in context. ${ }^{126}$ The Supreme Court has now quite clearly adopted the view that the Amendment should be understood to carry both proscriptions. ${ }^{127}$

123 See Daniel P. Polsby, The Death of Capital Punishment? Furman v. Georgia, 1972 SUP. CT. REV. 1, 27 (noting that pursuing nonarbitrariness in capital sentencing under the Eighth Amendment implicates a "profound contradiction").

${ }^{124}$ See generally Anthony F. Granucci, "Nor Cruel and Unusual Punishments Inflicted": The Original Meaning, 57 CAL. L. REV. 839, 842-44 (1969) (defining the debate over the original understanding of the Clause as whether certain forms of punishment were prohibited or whether punishments that were disproportionate to the charged offense were also or instead proscribed).

${ }^{125}$ See Furman, 408 U.S. at 263 (Brennan, J., concurring) (noting that the import of the Clause at the time of its adoption is indefinite).

${ }^{126}$ See Phillip E. Johnson, Cruel and Unusual Punishment, in 2 ENCYCLOPEDIA OF CRIME AND JUSTICE 575, 575 (Sanford H. Kadish ed., 1983) ("The history of the clause provides no conclusive answer to the recurring question of whether its American authors meant only to bar certain barbarous punishments altogether or whether they also meant to ban penalties, not unlawful per se, that are disproportionate to the crime.").

${ }^{127}$ See, e.g., Enmund v. Florida, 458 U.S. 782, $797-98$ (1982) (holding the death penalty impermissible for a defendant convicted of felony murder who did not intend to, attempt to, or actually kill); Coker v. Georgia, 433 U.S. 584, 592 (1977) (holding that the death penalty, although sometimes permissible, was disproportionate punishment for Coker's crime and, therefore, violative of the Eighth Amendment); see also sources cited infra note 137. 
Assuming the Eighth Amendment properly bans disproportional death sentences, that command does not call for consistency in the distribution of death sentences. A disproportionality command means that only persons who warrant the death penalty can receive that sanction. The protection does not mean that all persons who warrant the death penalty must receive it. Moreover, the offender who warrants the death penalty and receives it does not warrant the penalty any less because some others who also warrant the death sentence escape it. ${ }^{128}$ Indeed, to claim that the prohibition on cruel and unusual punishments mandates consistency is to obscure the true question to be addressed under the Eighth Amendment: When does a capital offender warrant the death penalty? The Court should ask whether there is a substantive Eighth Amendment value that determines when a death sentence is just.

The troubling problem of racial disparities in the use of the death penalty does not change the mandate of the Eighth Amendment. ${ }^{129}$ The Eighth Amendment proscribes the imposition of the death penalty on those who do not warrant it. Unless disparities justify a conclusion that those who receive the death sentence do not warrant it, racially based inconsistencies are irrelevant. For example, the Baldus study indicated that, in Georgia, killers of white victims were much

${ }^{128}$ See Ernest van den Haag, The Ultimate Punishment: A Defense, 99 HARV. L. REV. 1662,1663 (1986) ("To put the issue starkly, if the death penalty were imposed on guilty blacks, but not on guilty whites, or, if it were imposed by a lottery among the guilty, this irrationally discriminatory or capricious distribution would neither make the penalty unjust, nor cause anyone to be unjustly punished, despite the undue impunity bestowed on others.").

${ }_{129}$ A state's unequal treatment of capital offenders, of course, undermines its capital-sentencing scheme when that inequality violates the Fourteenth Amendment. It is possible for all offenders who receive the death penalty to warrant it in Eighth Amendment terms even though the selection process violates the Fourteenth Amendment. However, the Supreme Court has concluded that there must be an intent to discriminate based on an improper basis before a Fourteenth Amendment violation arises. See McCleskey v. Kemp, 481 U.S. 279, 292 (1987) (stating that a defendant who raises an equal-protection claim must establish "the existence of purposeful discrimination"” (quoting Whitus v. Georgia, 385 U.S. 545, 550 (1967))). One may disagree with this view of when disparate treatment should be actionable under the Fourteenth Amendment. See generally Charles R. Lawrence III, The Id, the Ego, and Equal Protection: Reckoning with Unconsciones Racism, 39 STAN. L. REV. 317, 35558 (1987) (contending that even unconscious racism should be actionable under the Fourteenth Amendment). Nevertheless, the goal of consistency in applying the death penalty may actually support increased use of the death penalty and the imposition of a greater percentage of death sentences on minority defendants. See infra notes 256-58 and accompanying text. 
more likely to receive the death penalty than killers of black victims. ${ }^{130}$ Studies in other states have produced identical findings. ${ }^{131}$ That some who warrant the death penalty escape that sanction, however, does not mean that others who are sentenced to death do not warrant death. ${ }^{132}$ While a situation can be hypothesized in which societal consensus rejects the imposition of death sentences as uniformly unwarranted, that does not appear to describe public sentiment about the death penalty in the United States. ${ }^{133}$

One may contend that improper racial considerations typically, if not inherently, infect death-penalty determinations, but this is neither a problem best understood as inconsistency nor a reason for further regulation of capital sentencing. This contention takes issue with the inability of decisionmakers to free themselves from improper considerations in pursuing a substantive Eighth Amendment standard for deciding when a death sentence is just. ${ }^{134}$ To prevail, the argument must establish that persons who do not warrant execution un-

${ }^{190}$ See supra notes 108-10 and accompanying text.

131 See, e.g., Samuel R. Gross \& Robert Mauro, Patterns of Death: An Analysis of Racial Disparities in Capital Sentencing and Homicide Victimization, 37 STAN. L. REV. 27, 105 (1984) (noting that race-of-the-victim disparities in the distribution of death penalties in the post-Furman systems of eight states "is a remarkably stable and consistent phenomenon").

${ }^{132}$ An offender warrants the death penalty even if many others who are similarly situated do not receive that sanction. As explained more fully in Part III, I believe that the pertinent Eighth Amendment value focuses on offender deserts, which are assessed based on the offender's character, record, and crime. See infra text accompanying notes 162-65. Of course, we cannot judge the deserts of an offender except by reference to our experience of judging the deserts of others. See LlOYD L. WEINREB, NATURAL LAW AND JUSTICE 244 (1987) ("Unable to reason from a general principle to specific applications, we build up a picture of the world from innumerable concrete instances; we learn how to regard one case after another and extend that learning to other similar cases."). Nonetheless, that many murderers who do not receive a death sentence are similarly situated to a defendant who receives it does not undermine the conclusion that the condemned offender deserves such a penalty.

195 See WHITE, supra note 62, at 24 (noting that recent polls reveal the public to be "overwhelmingly in favor of the death penalty"); Garvey, supra note 39, at 1047 (concluding based on recent polls and legislation that "the public's strong support for capital punishment shows little sign of abating").

${ }^{194}$ See, e.g., Interview by Ian Gray \& Moira Stanley with Alan M. Dershowitz, Professor at Harvard Law School, in Cambridge, Mass. (Mar. 2, 1988) [hereinafter Dershowitz], in A PUNISHMENT IN SEARCH OF A CRIME 330, 331 (Ian Gray \& Moira Stanley eds., 1989) (asserting that "[l]egal rules do not determine who gets executed," but rather a variety of factors irrelevant to the deserts of the offender generally determine capital-sentencing outcomes). 
der the Eighth Amendment are executed. ${ }^{135}$ In reality, this is an argument for eliminating capital punishment altogether rather than merely supervising capital sentencing. As we will see, the Court is unable to determine precisely who warrants the death penalty, and therefore, cannot define with accuracy those cases where the death penalty is just. ${ }^{136}$ Consequently, if one finds that racial prejudices generally infect death-penalty decisions, abolition, not regulation, is the appropriate remedy.

In the final analysis, the Court's oft-stated rationale for regulating capital-sentencing trials since Furman lacks a grounding in the Eighth Amendment. A prohibition on "cruel and unusual punishments" is not violated when offenders who warrant the death penalty escape it, but rather when offenders who do not warrant the death penalty receive it. The ironic outcome of long-term efforts to use the Eighth Amendment to apply the capital punishment consistently helps explain why the Court's purported focus on consistency remains more a rhetorical flourish than a guiding principle for deciding cases.

\section{THE SUCCESS AND FAILURE OF THE DESERTS-LIMITATION THEORY OF REGULATION}

Although the Supreme Court has failed to articulate an Eighth Amendment rationale for regulating capital-sentencing trials, the question remains whether one exists. This Part explains that there is a principle plausibly drawn from the Eighth Amendment that could govern the capital sentencer's decision. Nonetheless, this principle fails on prudential grounds to provide a rationale for such regulation. The relevant principle is that only those who deserve the death penalty should receive it. The deserts-limitation principle explains the function of a capital-sentencing hearing and provides a standard to guide the capital sentencer. Nonetheless, the principle loses its prescriptive power at a high level of generality. Because of the inability to refine the principle into relatively precise decisional standards or rules of evidentiary relevance, the Court cannot appropriately use it to regu-

${ }^{195}$ Based on the Court's view of the need to identify an enduring societal consensus against the death penalty, see infra text accompanying notes $158-60$, the Court effectively would have to find that there is a widespread view that those sentenced to death do not deserve that sanction. I do not believe that such a view exists and am doubtful that it would exist even if the racial disparities involved in capital sentencing were widely known.

${ }^{136}$ See infra text accompanying notes 175-77. 
late procedure at capital-sentencing hearings or even to require those hearings.

\section{A. The Explanatory Power of the Theory}

The principle that only offenders who deserve death should receive that sanction embodies the core restriction that the Constitution imposes on the use of capital punishment. This desertslimitation idea establishes that utilitarian considerations should not factor in the ultimate decision about whether an offender warrants the death penalty. A particular murderer may be extremely dangerous and offer little prospect for future contributions to society. Nonetheless, under the deserts limitation, she should not be condemned to death unless she deserves this sanction. This basic principle, rather than being a command for consistency, explains the underlying features of the Court's capital-sentencing doctrine.

A prohibition on undeserved capital sentences assumes that the Eighth Amendment proscribes not only punishments that are barbarous in form, but also those that are unduly severe in context. Although this proposition has been disputed, the Supreme Court long ago determined that the Eighth Amendment prohibits disproportionate penalties as well as those deemed inherently inhumane. ${ }^{137}$ The Court has never retreated from this position.

${ }^{157}$ In 1910, in Weems v. United States, 217 U.S. 349 (1910), the Court concluded that the prohibition covers a sanction that is excessive in application even though not proscribed per se. Weems was a Philippine official who had been convicted under Philippine law for falsifying a public document. See id. at 357-58. He was sentenced to cadena temporal, which involved at least twelve years of hard labor, perpetual supervision, and loss of his civil rights. See id. at 363-64. Justice McKenna, writing for the Court, struck down these penalties as cruel and unusual. He referred to the extreme and unusual nature of the accessory forfeitures, as well as to the excessive imprisonment imposed. See id. at 366 . The opinion also suggested that the Court thought that the sanctions were not per se improper but, instead, only improper based on the crime committed by Weems: "Such penalties for such offenses amaze those who... believe that it is a precept of justice that punishment for crime should be graduated and proportioned to offense." Id. at 366-67.

Some have doubted that the outcome in the Weems case would have been the same if only the prison sentence had been involved, suggesting that the Court viewed the accessory forfeitures to be proscribed per se. See, e.g., Herbert L. Packer, Making the Punishment Fit the Crime, 77 HARV. L. REV. 1071, 1075-76 (1964) ("[1]t was the combination of an excessive but conventional mode of punishment with a good deal of laid-on unpleasantness ... that supported the characterization of Weems' punishment as cruel and unusual."). Three members of the current Supreme Court also believe that the Eighth Amendment is best understood as only proscribing modes of punishment. See Graham v. Collins, 506 U.S. 461, 488 (1993) (Thomas, J., concurring) ("[T]he 
In assessing proportionality, the Court has acted on the view that offender culpability or blameworthiness for the capital crime is the appropriate standard in the capital context. In Coker $v$. Georgia, the Court concluded that death was always disproportionate to "a rape not involving the taking of life."138 After noting that death was an uncommon punishment for rape, Justice White, writing for a fourJustice plurality, ${ }^{139}$ declared that determining whether capital punishment was excessive punishment for rape was ultimately left to the discretion of the Court. ${ }^{140}$ The retributive basis for the plurality's conclusion was clear. Justice White emphasized that the invasion of personal interests involved in rape, although serious, was not commensurate with the taking of life itself. ${ }^{141}$ Justice White did not men-

better view is that the Cruel and Unusual Punishments Clause was intended to place only substantive limitations on punishments."); Harmelin v. Michigan, 501 U.S. 957, 976 (1991) (Scalia, J., joined by Rehnquist, C.J.) ("[T]he Clause disables the Legislature from authorizing particular forms or 'modes' of punishment.").

Despite room for debate, a substantial majority of the Court recently agreed that Weems correctly identified a prohibition in the Eighth Amendment against disproportional penalties. See id. at 997 (Kennedy, J., joined by O'Connor \& Souter, J., concurring in part and concurring in judgment) ("Our decisions recognize that the Cruel and Unusual Punishments Clause encompasses a narrow proportionality principle."); id. at 1009 (White, J., joined by Blackmun \& Stevens, JJ., dissenting) (arguing that while the Eighth Amendment does not explicitly refer to "proportionality," it clearly would be cruel and unusual "to impose any punishment that is grossly disproportionate to the offense for which the defendant has been convicted").

139433 U.S. 584, 599 (1977) (plurality opinion).

139 Three other Justices agreed with the judgment, one on narrower grounds, but two on broader grounds. Justice Powell concluded that the death sentence in Coker's particular case was excessive, but was unwilling to agree that death was always excessive for rape. See id. at 603 (Powell, J., concurring in judgment in part and dissenting in part) (" $[\mathrm{I}] \mathrm{t}$ may be that the death penalty is not disproportionate punishment for the crime of aggravated rape."). Justices Brennan and Marshall each separately concurred on grounds that the death penalty was unconstitutional in all circumstances. See id. at 600 (Brennan, J., concurring in judgment) ("[T]he death penalty is in all circumstances cruel and usual punishment prohibited by the Eighth and Fourteenth Amendments."); id. (Marshall, J., concurring in judgment) ("The death penalty, I concluded, is a cruel and usual punishment prohibited by the Eighth and Fourteenth Amendments.").

${ }^{140}$ See id. at 597 (plurality opinion) ("[O]ur own judgment will be brought to bear on the question of the acceptability of the death penalty under the Eighth Amendment.").

${ }^{141}$ See id. at 598 (plurality opinion) ("The murderer kills; the rapist, if no more than that, does not."). The opinion implied that the death penalty was per se unconstitutional for most crimes that did not involve "the taking of human life." Id. (plurality opinion). 
tion that punishing rape with death might serve utilitarian ends. ${ }^{142}$ The plurality opinion also indicated that Coker's responsibility for the rape at issue was the only proper measure of retribution. Although Coker had a horrendous record of murder and rapes, and was a prison escapee when he committed the charged offense, ${ }^{143}$ Justice White stated that those prior crimes did not affect the impropriety of the capital punishment. ${ }^{144}$ Thus, the opinion indicated that capital punishment is limited by the moral culpability of an offender for the charged offense, uninfluenced by the societal benefits of executing her. Further, the Court's subsequent applications of the Coker doctrine have continued to rest on retributive ideals, although the Court also has emphasized the need to examine whether the death penalty is rarely applied in the relevant category of cases. ${ }^{145}$

Mandating and closely regulating a capital-sentencing hearing might be considered an effort to pursue the same principle that animates the Coker doctrine. If the death penalty is inapplicable to categories of offenses in which the offender is insufficiently deserving, as Coker held, the offender's deserts, based on individualized facts, should also limit the imposition of the sanction. For example, the range of deserts of persons convicted even of aggravated murder is wide, and arguably, not all of them deserve the death penalty. According to this view, a sentencing hearing would allow evaluation of the deserts of the individual offender. Further, because dozens, or even hundreds, of factors might affect the deserts evaluation, the needed inquiry could not be adequately addressed by the definition of a capital offense. For this reason, a capital-sentencing hearing

${ }^{142}$ Cf. Packer, supra note 137, at 1079-81 (noting that if the desire to deter other future offenders or to incapacitate the convicted criminal justifies the death sentence, then rape is rationally punished with the death penalty).

${ }^{143}$ In his dissenting opinion, which pointed to the utilitarian benefits of executing Coker, Chief Justice Burger emphasized Coker's horrible record and his escape from prison to commit the charged crime. See Coker, 433 U.S. at 605 (Burger, C.J., dissenting).

${ }^{144}$ See id. at 598-99 (plurality opinion) (stating that "these prior convictions do not change the fact that the instant crime being punished is a rape not involving the taking of life").

145 See, e.g., Tison v. Arizona, 481 U.S. 137, 149 (1987) ("The heart of the retribution rationale is that a criminal sentence must be directly related to the personal culpability of the criminal offender."); see also Stanford v. Kentucky, 492 U.S. 361, 382 (1989) (O'Connor, J., concurring in part and concurring in judgment) (emphasizing that an appropriate Eighth Amendment analysis requires a consideration of whether there is a nexus between the punishment and the offender's blameworthiness for the crime); Penry v. Lynaugh, 492 U.S. 302, 336 (1989) (plurality opinion) (quoting the same language from Tison). 
would be essential. The individualized inquiry allows a refined assessment of deserts in order to ensure that no person is sentenced to death who does not warrant that sanction.

The deserts-limitation principle does not require that all capital offenders who deserve death receive this sanction. Instead, the principle only requires that those who do not deserve the sanction be spared. The deserts-limitation theory is not concerned with consistent treatment of capital offenders. Even if most people who deserve death only serve prison sentences, the death sentences that do issue would not be cruel and unusual. As long as offenders who receive the death penalty deserve it, they could not claim that their punishment violates the Eighth Amendment. ${ }^{146}$

Although the Court espouses a "consistency" theory for regulating capital sentencing, in most ways its capital-sentencing holdings are best explained by appeal to the deserts limitation. First, the desertslimitation principle could explain why the Court has not regulated all stages of the capital-selection process. ${ }^{147}$ A goal of consistency in capital sentencing only makes sense as part of an effort to protect against arbitrariness throughout the capital-selection process. ${ }^{148}$ By contrast, even without regulation at other stages, requiring a sentencing hearing to assess deserts can be thought to help ensure that all capital offenders who receive a death sentence deserve it.

The deserts-limitation principle also can help explain some of the Court's doctrine that regulates the sentencing trial. First, the theory can provide some support for the Court's requirement that a sentencing hearing be held in every capital case, even if the state defines the

${ }^{146}$ The Eighth Amendment plausibly can be interpreted to proscribe undeserved death penalties. The intended meaning of the prohibition against "cruel and unusual punishments" is uncertain, as we have seen. See supra notes 125-26 and accompanying text. However, the concept that a person should not suffer an undeserved death sentence coincides with shared notions of justice. See, e.g., ANDREW VON HIRSCH, DOING JUSTICE: THE CHOICE OF PUNISHMENTS 45 (1976) ("Ask the person on the street why a wrongdoer should be punished, and he is likely to say that he 'deserves' it."); John Hospers, Retribution: The Ethics of Punishment, in ASSESSING THE CRIMINAL 181, 183 (Randy E. Barnett \& John Hagel III eds., 1977) (contending that, for most people, the idea of treating criminals in accordance with their "deserts" embodies the very notion of justice). According to this view, undeserved death sentences constitute cruel and unusual punishment. See, e.g., Trop v. Dulles, 356 U.S. 86, 101 (1958) (plurality opinion) (asserting that the Cruel and Unusual Punishments Clause "draw [s] its meaning from the evolving standards of decency that mark the progress of a maturing society").

${ }^{147}$ See supra Part II.A.1.

${ }^{148}$ But see supra Part II.A (arguing that the "nonarbitrariness" rationale for capitalsentencing regulations is not supported by the Court's rulings). 
capital crime in highly specific terms. ${ }^{149}$ This argument suggests that a proper deserts assessment can only be achieved through an individualized sentencing inquiry encompassing potentially dozens of factors. Based on this view, the state cannot mandate death even for aggravated crimes defined in narrow terms.

The deserts theory, more than the consistency doctrine, also justifies the narrowing command embodied in the Court's capitalsentencing doctrine. As we have seen, the Court has concluded that a state must have narrowing factors, however minimal, that reduce the size of the group potentially subject to the capital punishment. ${ }^{150}$ As previously discussed, this requirement makes little sense if the goal is consistency in the distribution of death sentences. ${ }^{151}$ If the goal is to protect against retributive excess, however, distilling the group that is eligible to receive death to the more deserving serves that purpose. Eliminating offenders whose crimes involve no aggravating factors diminishes the chances that an undeserving offender will be sentenced to death.

In addition, the deserts-limitation theory, unlike the consistency theory, explains the Court's mandate of broad, individualized consideration. The Court has required that the capital sentencer remain free to reprieve a capital offender based on any mitigating evidence that the offender presents regarding her character, record, or crime. ${ }^{152}$ If consistency is the goal, this requirement is illogical since it opens the door for sentencers to react without channeling standards to a broad swath of potentially mitigating information, making it more likely that the outcome will be controlled by the values of the particular sentencer rather than the influence of the evidence presented. By contrast, if the deserts-limitation principle drives the inquiry, inconsistent sentencing outcomes are not necessarily problematic. As long as the practice helps to spare offenders who do not deserve the death penalty, it serves the theoretic goal.

Another much-discussed conflict in capital-sentencing cases also disappears if regulation is based on a deserts limitation rather than consistency concerns. The Justices themselves have frequently

${ }^{149}$ See, e.g., Sumner v. Shuman, 483 U.S. 66, 82-85 (1987) (rejecting mandatory death statute as applied to murder by an inmate serving a life term); Roberts v. Louisiana, 431 U.S. 633, 637-38 (1977) (rejecting mandatory death penalty for the murder of a police officer).

\footnotetext{
${ }^{150}$ See supra text accompanying notes 52-57.

151 See supra text accompanying notes 78-79.

${ }^{152}$ See supra Part I.B.
} 
claimed that there is a "tension" between the Furman command of "consistency" and the requirement of individualized consideration embodied in Lockett and its progeny. ${ }^{153}$ The existence of a true tension is undermined, however, by the lack of any continuing controversy about what a state must do to create a constitutional system of capital sentencing. ${ }^{154}$ States need only require the finding of murder plus one aggravating factor and subsequently allow for unbridled consideration of mitigating circumstances. ${ }^{155}$ The Court has never imposed, except rhetorically, a mandate that states promote "consistency." The purported conflict exists only in the language of the Court's opinions, not in the schemes the Court has approved. Substituting the deserts limitation for consistency as the regulatory theory, moreover, solves even this rhetorical conflict. Harmonization is possible because a theory of deserts limitation justifies rather than undermines individualized consideration.

The Court's capital-sentencing doctrine, however, does not conform entirely to the deserts-limitation theory. ${ }^{156}$ The Court has not, for example, required that aggravating circumstances focus on offender deserts as opposed to utilitarian questions, such as the offender's propensity for future violence. The Court has not required that the evidence or argument presented be limited to information bearing on deserts; prosecutors are free to offer evidence of future dangerousness and to urge execution, for example, to spare prison guards from the offender's future violence. The Court has not even required that capital sentencers be advised about the substantive question to be resolved at the sentencing hearing. Thus, sentencers may legitimately vote for death based on the perceived benefits of execution to the community rather than on the deserts of the of-

153 See supra note 102 and accompanying text.

${ }^{154}$ See, e.g., Steiker \& Steiker, supra note 3, at 371 (" [I]f a state sought to design a capital statute from scratch today, it could easily avoid federal constitutional difficulties and, perhaps more tellingly, could do so without departing significantly from the statutory schemes struck down in Furman.").

135 See supra Part I.B-C.

156 The Court has stated several times in recent years that the individualization requirement stems from the need to assess offender culpability. See, e.g., McKoy v. North Carolina, 494 U.S. 433, 443 (1990) ("' [I]t is precisely because the punishment should be directly related to the personal culpability of the defendant that the jury must be allowed to consider and give effect to mitigating evidence relevant to a defendant's character or record or the circumstances of the offense." (quoting Penry v. Lynaugh, 492 U.S. 302, 327-28 (1989))). However, the Court has never required that jurors be told of the substantive question to answer regarding culpability, or that evidence and argument of counsel be limited by the culpability standard. 
fender. These inconsistencies could be remedied by the Court and, indeed, the Court should have pursued these problems when it rejected mandatory death statutes and regulated capital-sentencing hearings under the Eighth Amendment. Despite the failure of the Court to pursue the deserts theory, careful consideration of the difficulties the Court would have encountered by pursuing it is warranted.

\section{B. The Failure of the Theory on Prudential Grounds}

Ultimately, the deserts-limitation principle fails as a theory by which to regulate capital sentencing. Although some would surely disagree, I contend that the fatal flaw is not with the basic notion that the Eighth Amendment commands that the death penalty be limited to those who deserve this punishment. As discussed above, the deserts theory provides a plausible interpretation of the prohibition on cruel and unusual punishments. As an explanation of a mandated capital-sentencing inquiry, the deserts notion wins by default; no other theory can explain why the Eighth Amendment always commands a sentencing inquiry as a prerequisite to a death sentence. ${ }^{157}$ The deserts principle also bears on what a capital sentencer should decide at the capital-sentencing hearing and, for that reason, provides a theoretical basis for regulating the inquiry. Although the desertslimitation principle is morally justified in the abstract, and explains some current Court practice, prudential reasons render the theory a failure. I believe that the Supreme Court cannot legitimately refine the deserts-limitation command sufficiently to justify controlling, or even requiring, the capital-sentencing hearing. For this reason, I conclude that the effort begun with Furman to regulate capital-

${ }^{157}$ Providing individualized consideration, through holding a sentencing hearing, does not automatically render a death sentence more humane. The hearing could only protect against a disproportional death sentence to the extent that it resolves some particular inquiry required by the Eighth Amendment as a prerequisite to a death sentence. Some commentators have concluded, however, that the Supreme Court's cases may mean that individualized consideration renders a death sentence acceptable without regard to the questions resolved at the hearing. See, e.g., Ronald J. Mann, The Individualized-Consideration Principle and the Death Penalty as Cruel and Unusual Punishment, 29 Hous. L. REV. 493, 515-16 (1992) (suggesting that individualized consideration is the sole constitutional requirement, regardless of the rationality of the results). Although I contend that such a position would be unfounded, I concede that the Court's incoherence in capital-sentencing decisions suggests that the Court does not believe that any particular question more specific than whether the offender is to be executed must be answered. 
sentencing procedure under the Eighth Amendment was destined to fail.

The problem stems from the proposition that the Court should interpret the Eighth Amendment in accordance with societal values. The Court has concluded that "the Amendment recognizes ... the 'evolving standards of decency that mark the progress of a maturing society."'158 Some may decry this approach on formalist grounds as too "activist." But at least this approach recognizes the Court's duty to restrict its review under the Eighth Amendment to enforcing humanitarian limits on punishment that are sufficiently clear as to warrant a finding of an enduring societal consensus. Room for argument remains about how to identify the relevant societal consensus. ${ }^{159}$ Still, when confronted with a vague clause like that prohibiting "cruel and unusual punishments," the effort to pursue society's deeper values appears to be the most appropriate approach to the Court's necessary task of articulating moral values. ${ }^{160}$

The difficulty for the Court in pursuing the deserts limitation in regulating the capital-sentencing trial is that no evident consensus exists as to how to refine the deserts measure. ${ }^{161}$ It may be intuitive that societal members generally believe that those who do not deserve the death penalty should not receive it. However, the consensus dissolves over how to refine the deserts measure in a way that can justify the Court's ignoring legislative judgments about how to structure the capital-sentencing hearing.

Initially, it is uncertain even at what level deserts are to be measured. Should the required assessment be of the offender's "culpability" for the capital crime, or instead, of her "moral merit"-her "general deserts"-determined by evaluating anything morally good or bad that she has done in her life? ${ }^{162}$ A culpability inquiry would ask only about the offender's "blameworthiness" or personal "responsibil-

${ }^{158}$ Ford v. Wainwright, 477 U.S. 399, 406 (1986) (quoting Trop v. Dulles, 356 U.S. 86, 101 (1958) (plurality opinion)).

${ }^{159}$ For criticism of the societal-consensus methodology in constitutional interpretation, see JOHN HART ELY, DEMOCRACY AND DISTRUST 63-69 (1980).

${ }^{160}$ See generally Richard H. Fallon, Jr., Of Speakable Ethics and Constitutional Law: A Review Essay, 56 U. CHI. L. REV. 1523, 1543 (1989) ("A judge should seek to interpret the community's values and bring them to bear on constitutional interpretation ....").

${ }^{161}$ See WeINREB, supra note 132, at 217 ("Desert... is not often put to the test of specificity and even resists it.").

${ }^{162}$ For discussion of the origin and meaning of these terms, see supra notes $98-99$ and accompanying text. 
ity" for the capital crime. ${ }^{163}$ This inquiry would start with the details of the crime and the defendant's involvement. It would also allow evidence of the defendant's background and character to the extent of inquiring whether factors external to the offender's responsible self so influenced her involvement in the crime as to reduce her culpability. ${ }^{164}$ A host of factors might be proffered to the sentencer about the defendant's past and about her emotional and mental condition. However, the evidence and inquiry would be restricted by the limited purpose of assessing the offender's responsibility for the capital offense. ${ }^{165}$

In contrast, if the required assessment is at the level of the offender's general "moral merit," all of the good and bad that she has produced and the motivations behind her life's works bear weight. The defendant could introduce evidence, for example, that she had won medals for valor during military service, that she had excelled in artistic endeavors, and even that she had been affectionate with dogs. In response, the prosecutor could detail all of the defendant's prior bad acts, ranging from major offenses to such minor matters as the failure to show respect to employers. Prior good and bad deeds would not bear on the narrow question of the offender's culpability

${ }^{163}$ Professor Wise has helpfully described how this inquiry would go beyond the culpability assessment involved in the conclusion that the defendant is guilty:

Culpability for purposes of sentencing .... seems to imply the relevance of considerations usually ignored when one has to say guilty or innocent, with no ifs and buts allowed. It may be taken to imply a somewhat greater concern with subjective, inner states of mind and feeling than is convenient or conventional in most legal contexts.

Edward M. Wise, The Concept of Desert, 33 WAYNE L. REV. 1343, 1353 (1987).

${ }^{164}$ This showing might include:

$[E]$ vidence that... the defendant's personal responsibility is lessened by youth, stunted intellectual and emotional growth, mental retardation or impaired capacity, mental or emotional disturbance, provocation by others, insanity, the influence of alcohol or drugs at the time of the offense .... [and] evidence... that the defendant suffered tragic or horrible circumstances in his or her formative years, such as abuse, neglect, poverty, or domestic turbulence....

Louis D. Bilionis, Moral Appropriateness, Capital Punishment, and the Lockett Doctrine, 82 J. CRIM. L. \& CRIMINOLOGY 283, 302-04 (1991) (footnotes omitted); see also Gary Goodpaster, The Trial for Life: Effective Assistance of Counsel in Death Penalty Cases, 58 N.Y.U. L. REV. 299, 324 (1983) (asserting that defense counsel must inquire "into the client's childhood, upbringing, education, relationships, friendships, formative and traumatic experiences, personal psychology, and present feelings").

${ }^{165}$ There is no single theory of culpability, however. On this score, see infra text accompanying notes $170-72$. 
for the crime. However, the sentencer should be made aware of these factors if the goal is to judge the offender's "soul." 166

It is not intuitive which measure of deserts ought to determine a capital offender's fate. Commentators have disagreed whether the Eighth Amendment notion of deserts speaks to a measure that is broader than offender culpability. ${ }^{167}$ While extending the inquiry beyond offender culpability renders it difficult to control, limiting the inquiry to culpability does not seem to comport with societal consensus. If culpability were the only relevant measure, prior crimes for which the offender had served her sentence arguably would have no influence on the capital sentencer's decision. Prior crimes for which one has served the sentence arguably lack any bearing on one's culpability for a later crime. ${ }^{169}$ Yet, it is not clear what most people would conclude about whether the offender's prior crimes should be included in the capital-sentencing inquiry. Likewise, a culpability focus would mean that the offender could not, for example, introduce evidence that she had saved a jail guard from a fatal stabbing while incarcerated pending trial on the capital charge. A defendant's good deed unrelated to the crime would not bear on her culpability for that crime. Yet, a consensus may well exist that an offender's unusual act of valor should be weighed in assessing her deserts at the sentencing hearing. ${ }^{169}$

${ }^{166}$ See Michel Foucault, DisciPline AND PUNISH 18 (Alan Sheridan trans., 1977) (asserting that the function of criminal courts over time has transformed from a mere "apportioning of responsibility" for the crime to a broader assessment of the offender's "soul").

${ }_{167}$ Compare Goodpaster, supra note 164, at 303 (asserting that a "central issue" of the inquiry "is the meaning and value of the defendant's life"), and Howe, supra note 98, at 350-58 (arguing for dual inquiries into culpability and general deserts), with Garvey, supra note 39, at 1022-29 (contending that the inquiry should focus on culpability and that the mandated inquiry under Lockett is arguably too broad), and Steiker \& Steiker, supra note 99, at 858 (contending that the societal consensus is too sketchy beyond the culpability measure).

${ }^{163}$ See Howe, supra note 98, at 352 n.114 (describing a variety of theories regarding the relevance of past crimes at sentencing).

${ }^{169}$ The Court's plurality decision in Coker v. Georgia, 433 U.S. 584 (1977), implied that the capital sentencer should be required to find that the defendant's culpability alone warrants the death penalty. Although Coker had committed prior crimes, including two rapes and a murder, and had escaped from prison to commit the rape for which he was tried, the plurality found that the offender's deserts regarding the charged offense should limit his eligibility for death. See id. at 598-99 (plurality opinion). The Coker decision does not, however, mean that the culpability finding would alone be sufficient to justify a death sentence. Rather, sufficient culpability could be one of two findings required as the prerequisite to a death sentence. The sentencer could also be required to find that, on the question of general moral merit, the 
Even if the Court could legitimately choose culpability over moral merit, doubt would remain over how to refine a culpability measure. Philosophers cannot agree on the basic explanation for when a person becomes morally responsible for an act or how to measure that responsibility. ${ }^{170}$ They certainly cannot agree on how to determine when a partial excuse sufficient to reduce a death sentence to a prison sentence should adhere. ${ }^{171}$ Are actors generally free from determinism and, for this reason, culpable? If so, why is an actor ever only partially culpable? If all acts are determined, when are actors still sometimes culpable, and under what circumstances? If determinism prevails, when would actors be only partially culpable? Philosophers have given a wide array of answers to these kinds of questions. ${ }^{172}$ In light of their disagreements, little basis exists to conclude that the citizenry has reached a consensus about how to scale the moral culpability of capital murderers.

Moreover, it is doubtful that consensus exists about the relative amount of retribution involved in the competing sanctions of imprisonment and death, since citizens disagree about the amount of suffering accompanying a long prison sentence. ${ }^{173}$ Judgments here must take account of the particular offender, for what may bring severe suffering for one may cause little hardship for another. The citizenry may be even less certain what retribution is achieved with death. Indeed, some may doubt that execution is more punitive than a long

offender deserves death. The question the Court would have to answer, its proportionality decisions suggest, is whether there is a societal consensus against executing a defendant whose overall moral merit indicates that she does not deserve death. See Steiker \& Steiker, supra note 99, at 839 n.18 (asserting that an analysis based on societal consensus employed in "proportionality" decisions such as Coker "can be employed to determine which evidence is constitutionally relevant to the capital sentencing decision, even where such evidence does not categorically preclude imposition of the death penalty").

${ }^{170}$ See generally Scott W. Howe, Reassessing the Individualization Mandate in Capital Sentencing: Darrow's Defense of Leopold and Loeb, 79 IOWA L. REv. 989, 1012-24 (1994) (discussing disagreement among contemporary philosophers as to Clarence Darrow's argument that no person is culpable, and thus, no person deserves punishment).

171 See generally id. at 1024-28 (explaining that analysis of the first-level inquiry into who should properly be punished based on Darrow's arguments leads to difficulties in formulating a theory for grading the severity of punishment due those deemed punishable).

${ }^{172}$ For a discussion of criminal-law theorists' views about the criminal law's acceptance of excuses, see $i d$ at 1028-36.

${ }^{179}$ See John E. Coons, Consistency, 75 CAL. L. REV. 59, 89 (1987) (asserting that a "dissensus" exists among both jurors and judges as to the "weights" to be accorded "the consequences of prison and death"). 
prison term. ${ }^{174}$ These disagreements cast further doubt on the notion that consensus exists about how to judge when a capital offender deserves death.

Current capital-sentencing doctrine underscores that the Court views itself as unable to provide standards for deciding which offenders deserve death. The Court's narrowing doctrine does not attempt to define who is death eligible. Although the Court has required the identification of an aggravating factor, it has not clarified what is aggravating, and has not required that a sentencing system as a whole significantly narrow the group of eligible offenders. ${ }^{175}$ Further, the Court's broad individualization mandate only means that, after death eligibility is established under state standards, sentencers must remain free to reject the death penalty based on evidence the offender offers concerning her character, record, or crime. Capital sentencers receive no channeling standard to help them resolve which offenders deserve the death penalty. The Court's decisions generally indicate that such an effort to channel the sentencer's decision would violate the Eighth Amendment. ${ }^{176}$ The sentencer must remain largely unrestricted in her use of the defendant's proffered evidence. ${ }^{177}$

The inability to define who deserves the death penalty undermines the Supreme Court's effort under the Eighth Amendment to regulate the capital-sentencing trial, or even to require the proceeding. Assume a defendant has been convicted of an aggravated murder, such as intentionally killing a police officer. We should ask why a state legislature lacks the authority to mandate the death penalty upon conviction for this crime. To conclude that the death penalty is inappropriate without considering the offender's background, character, and crime assumes that there may be factors that reduce the

${ }^{174}$ See Douglas Mossman, The Psychiatrist and Execution Competency: Fording Murky Ethical Waters, 43 CASE W. RES. L. REV. 1, 58 n.231 (1992) (asserting doubt that execution is always more punitive than life imprisonment and noting that several prominent writers "have viewed life imprisonment as a worse fate than death").

${ }^{175}$ See supra notes $80-87$ and accompanying text.

${ }^{176}$ See supra notes $96-100,103$ and accompanying text.

${ }^{177}$ In its effort to define when a defendant is actually uinnocent of the death penalty" and, thus, may be allowed a departure from the normal rules governing federal habeas corpus petitions, the Court also has declined to address when a death sentence is truly warranted. See Sawyer v. Whitley, 505 U.S. 333, 345 (1992). The Court has concluded that, as long as the existence of at least one aggravating factor still remains clear, new evidence bearing on sentencing cannot establish that the offender is "innocent" of the death penalty. See id. at 345-47 (rejecting the argument that the offender should be permitted to show the existence of additional mitigating evidence to establish her "innocence of the death penalty"). 
offender's deserts, rendering the death penalty undeserved. However, unless the Court can specify the standards to be applied by the sentencer, the only real issue is who decides how deserts should be measured. It remains unapparent why individual sentencers should be able to decide for themselves how to define deserts, which is the effect of the Court's doctrine. The basis for disqualifying the legislature from providing the standards disappears if the Court itself cannot articulate Eighth Amendment standards that should control the sentencing decision.

The Court's rejection of legislative judgment as to appropriate sentencing standards is all the more strange given its conclusion that single judges may serve as capital sentencers. ${ }^{178}$ It is particularly unapparent why a single judge should be allowed to decide what line separates those who warrant the death sentence from those who do not when the legislature is disqualified from doing so. The failure to provide standards requires the sentencing judge not only to decide whether the defendant falls within the category of offenders warranting death, but also to define the category. If political processes render the legislatures untrustworthy to define the category appropriately, it is ironic that the Court would authorize states to turn the process over to a single judge. In death-penalty states, judges are often elected and face severe political pressure in death-penalty cases. $^{179}$

${ }^{178}$ The Court has repeatedly rejected claims that a jury rather than a judge must perform the capital-sentencing inquiry and decision. See, e.g., Walton v. Arizona, 497 U.S. 639, 647-49 (1990) (rejecting the argument that the Sixth Amendment requires a jury trial on the sentencing issue of life imprisonment or death); Clemons $v$. Mississippi, 494 U.S. 738, 745 (1990) ("Nothing in the Sixth Amendment as construed by our prior decisions indicates that a defendant's right to a jury trial would be infringed where an appellate court invalidates one of two or more aggravating circumstances found by the jury, but affirms the death sentence after itself finding that the one or more valid remaining aggravating factors outweigh the mitigating evidence."); Hildwin v. Florida, 490 U.S. 638, 640-41 (1989) (per curiam) ("[T]he Sixth Amendment does not require that the specific findings authorizing the imposition of the sentence of death be made by the jury."); Spaziano v. Florida, 468 U.S. 447, 465 (1984) (concluding "that there is no constitutional imperative that a jury have the responsibility of deciding whether the death penalty should be imposed"); Proffitt v. Florida, 428 U.S. 242, 252 (1976) (plurality opinion) (explaining that jury sentencing in a capital case is not constitutionally required).

${ }^{179}$ See generally Stephen B. Bright \& Patrick J. Keenan, Judges and the Politics of Death: Deciding Between the Bill of Rights and the Next Election in Capital Cases, 75 B.U. L. REv. 759, 760 (1995) ("[U]npopular decisions in capital cases, even when clearly compelled by law, may cost a judge her seat on the bench, or promotion to a higher court."). 
The argument that sentencing jurors or judges will do no worse than the legislature in refining the rules for identifying felons who deserve the death penalty is not persuasive. First, for the same reason that the Court cannot identify sentencing rules, the Court cannot determine the extent to which sentencing jurors and judges apply correct standards for determining offender deserts. No standard of measurement exists because no consensus exists, articulable in relatively precise rules, about when a death sentence is deserved. Moreover, the argument shifts the burden in the wrong direction. If the Court cannot articulate fairly specific rules, derived from the Eighth Amendment, governing when a death sentence is deserved, the default decision should go to the legislative judgment. Again, the argument is about who should identify the rules of decision, and, given the desire to pursue societal values, a large body elected by the citizenry to represent it would appear better than a judge or a jury. ${ }^{180}$

The Court's doctrine has, moreover, substantially constricted legislative options on capital sentencing. It is possible that many legislatures, even without Supreme Court action, would have enacted and maintained capital-sentencing systems similar to those called for under the Court's doctrine. It should be noted that, even before Furman, there was an evolving movement by state legislatures toward the sort of sentencing approach that the Court subsequently required in the decisions that followed Furman. ${ }^{181}$ Many state legislatures might well have further narrowed the application of the death penalty even without Furman, and most probably would have allowed fairly broad, individualized consideration. This does not mean, however, that all

${ }^{180}$ Cf. ELY, supra note 159 , at 68 (arguing that the Court is not a better representative of societal values than a national legislature).

${ }^{181}$ When Furman was decided, a majority of states still employed a unitary trial in capital cases, but a trend was developing toward employing a bifurcated sentencing hearing that would allow for the presentation of more evidence bearing on the sentencing issue. California and Pennsylvania adopted bifurcated trials in the late 1950s. See Note, California and Pennsylvania Courts Divide on Question of Admissibility of Details of Prior Unrelated Offenses at Hearing on Sentencing Under Split Verdict Statutes, 110 U. PA. L. REV. 1036, 1038-39 (1962). Connecticut, New York, and Texas adopted bifurcated trials during the 1960s. See Charles J. Judson et al., Project, A Study of the Califormia Penalty Jury in First-Degree-Murder Cases, 21 STAN. L. REv. 1297, 1307 \& n.10, 1432-38 (1969). In 1970, Georgia adopted a procedure involving a separate sentencing hearing at which the prosecutor could introduce evidence of the defendant's prior record. See BALDUS STUDY, supra note 64, at $8 \mathrm{n}$. (noting that Georgia was one of a few states that adopted a bifurcated system before 1972). Shortly before Furman was decided, Florida adopted a bifurcated procedure so that both sides could offer evidence relevant to sentencing at a separate sentencing trial. See Ashley v. State, 265 So. 2d 685, 692 (Fla. 1972) (pointing to legislative enactment of the new procedure). 
states would have employed broad, discretionary sentencing or that only those systems should be approved. States should have been permitted to experiment with other approaches.

In sum, the deserts limitation cannot be refined to the point of regulating a capital-sentencing trial. The capital sentencer should consider evidence of the offender's deserts and render a judgment that involves a deserts finding as a prerequisite to any death sentence. Yet, to the extent that the legislature defines the standards for resolving who will receive death, the legislature simply becomes the sentencer. The Court cannot deny that legislative standards appropriately should define deserts without explaining why the legislative standards fail. The Court's capital-sentencing decisions underscore, however, that the Court is unable to define who deserves death.

\section{WHAT'S LEFT AFTER DEREGULATION OF THE CAPITAL-SENTENCING TRIAL?}

The deregulation of capital sentencing under the Eighth Amendment does not equate with the constitutional deregulation of capital punishment. The Court has pursued, and might still legitimately pursue, constitutional fairness in capital-punishment systems. The Court's requirements of narrowing and broad, individualized sentencing consideration have actually provided rationalizations for failing to impose adequately other legitimate restrictions on the death penalty. Eliminating the narrowing and individualization doctrines would encourage rethinking how the Constitution, particularly the Eighth Amendment, might plausibly be understood to regulate the use of capital punishment.

\section{A. The Proportionality Doctrine}

The Court's most important weapon against improper use of the death penalty is embodied in its proportionality doctrine. As previously noted, a four-Justice plurality used this mandate in Coker $v$. Georgia to proscribe the death penalty for rape. ${ }^{182}$ In Coker, the plurality strongly implied that the death penalty was per se inapplicable to most serious crimes that did not involve the taking of human life,

${ }^{182} 433$ U.S. 584, 599 (1977) (plurality opinion); see supra notes $138-45$ and accompanying text (discussing Coker). 
such as burglary or robbery, even if committed while armed. ${ }^{188}$ The plurality found that the death penalty amounted to retributive excess when compared to the culpability associated with rape. ${ }^{184}$ Subsequently, the Court has held the death penalty categorically impermissible for certain murderers who fall within the fringe of the felonymurder doctrine. In Enmund v. Florida, the Court held the death penalty impermissible for one guilty of felony murder who did not intend to, attempt to, or actually kill. ${ }^{185}$ In Tison $v$. Arizona, the Court largely eviscerated the Enmund rule by allowing the death penalty even for offenders who fell within the Enmund exception as long as they exhibited reckless indifference to human life and were major participants in the underlying felony. ${ }^{186}$ Nonetheless, a few murderers remain categorically exempt from the death penalty on the ground that they do not deserve that sanction. ${ }^{187}$

${ }^{183}$ By emphasizing that rape was among the most serious of crimes, but nonetheless one that did not involve "the unjustified taking of human life," Coker, 433 U.S. at 598 (plurality opinion), the plurality implied that other serious crimes in which life was not taken were also per se impermissible bases for a death sentence. The opinion did not foreclose, however, the possibility that situations might remain in which the death penalty would apply although no one died, such as for crimes producing a great risk of harm to many people.

${ }^{184}$ Although the plurality pointed out that Coker's crime involved the "rape of an adult woman," id. at 592 (plurality opinion), its reasoning would also apply to the rape of a child. See JOSHUA DRESSLER, UNDERSTANDING CRIMINAL LAW 45 n.31 (2d ed. 1995) ("Language in Coker suggests that the decision is limited to the rape of adult women, but its reasoning clearly applies to rape of children, as well.").

${ }^{185} 458$ U.S. 782, 797 (1982) (" $[W]$ e have the abiding conviction that the death penalty ... is an excessive penalty for the robber who, as such, does not take human life."). This view of the Enmund standard was confirmed four years later in Cabana $v$. Bullock, 474 U.S. 376, 384-86 (1986). Bullock also made clear that the finding could be made by a reviewing court rather than by the sentencer. See id. at 386 ("[T] he decision whether a sentence is so disproportionate as to violate the Eighth Amendment... has long been viewed as one ... an appellate court is fully competent to make.").

${ }^{186} 481$ U.S. 137, 158 (1987) (holding that "major participation in the felony committed, combined with reckless indifference to human life, is sufficient to satisfy the Enmund culpability requirement").

${ }^{187}$ In Ford v. Wainwright, 477 U.S. 399 (1986), the Court also banned the execution of insane prisoners. The Ford decision did not bar the execution of those who were insane at the time of their offense but subsequently recovered. It held, instead, only that one cannot be executed while insane. This decision was grounded, however, not simply on an interpretation of contemporary standards of decency, but also on the conclusion that execution of the insane was considered inhumane at the time of the founding and that the Eighth Amendment proscribes acts of punishment considered indecent when the Bill of Rights was adopted. See id. at 405-10, 409 (explaining that today, as well as during the 18 th century, civilized societies reject "killing one who has no capacity to come to grips with his own conscience or deity"). 
While some of the Court's proportionality decisions have helped to ensure that only the deserving receive capital punishment, they have also helped to reduce the influence of race on the distribution of death penalties. In the decades before Furman, the most pronounced racial disparities existed for the crime of rape, in which the death penalty was imposed disproportionately for the rape of a white woman by a black defendant. ${ }^{188}$ In fact, the racial disparity in the distribution of death sentences in rape cases apparently spurred the campaign against the death penalty in the 1960s. In 1963, Justice Goldberg wrote a dissent from a denial of certiorari in Rudolph $v$. Alabama, ${ }^{189}$ a case in which a black man had been sentenced to death for raping a white woman. In that dissent, joined by Justices Douglas and Brennan, Justice Goldberg raised questions about the constitutionality of the death penalty for rape. ${ }^{190}$ Although Justice Goldberg did not discuss the racial disparities, they apparently were his central concern. ${ }^{191}$ It was the dissent in Rudolph that helped spur the campaign by lawyers at the NAACP Legal Defense Fund that ultimately led to the Furman decision. ${ }^{192}$ After the Court authorized the resumption of the death penalty in 1976, and Georgia attempted to enforce its new death-penalty statute for rapes, the Supreme Court reached

${ }^{18 s}$ See James R. Acker, Social Science in Supreme Court Death Penalty Cases: Citation Practices and Their Implications, 8 JUST. Q. 421, 431 (1991) (noting cases where socialscience materials were presented to the Court to highlight the discriminatory application of the death penalty in rape cases); see also MICHAEL MELTSNER, CRUEL AND UNUSUAL: THE SUPREME COURT AND CAPITAL PUNISHMENT 75 (1973) (noting that between 1930 and 1967, 405 of 455 death sentences for rape were imposed on black men).

${ }^{189} 375$ U.S. 889 (1963).

${ }^{190}$ See id. at 889-90 (Goldberg, J., dissenting from denial of certiorari) (questioning whether imposing the death penalty for rape violates standards of decency).

${ }^{191}$ Professor Dershowitz, who was Justice Goldberg's clerk that year, has stated that the racial disparities were the Justice's primary concern:

We had done a study and had found four hundred or so cases in which people were sentenced to death for rape. It was always a black man sentenced to death for raping a white woman. So we took that case to ask if the Court would simply like to consider the question.

Dershowitz, supra note 134, at 331.

192 See Eric L. Muller, Note, The Legal Defense Fund's Capital Punishment Campaign: The Distorting Influence of Death, 4 YALE L. \& POL'Y REV. 158, 166-67 (1985) (asserting that the Rudolph dissent was one of several factors that caused lawyers at the NAACP Legal Defense Fund to begin to focus on attacking the constitutionality of the death penalty); see also Dershowitz, supra note 134, at 331 (asserting that after Dershowitz sent copies of the dissenting opinion in Rudolph to Professor Anthony Amsterdam, who worked closely with the NAACP Legal Defense Fund, "Tony picked up the ball and ran with it and started the campaign against the death penalty, which culminated in Furman"). 
the central question presented by the Rudolph dissenters in Coker. By holding the death penalty per se improper for most nonhomicide offenses, particularly rape, the Court eliminated a category of death eligibility with a pernicious history of racial disparities. ${ }^{193}$

The Court could appropriately have enforced the proportionality doctrine more vigorously than it has since Coker to help ensure that only deserving capital offenders receive death sentences. In rejecting claims of group disproportionality, the Court may well have considered the existence of individualized consideration by the capital sentencer as a reason to be less concerned about the need to draw categorical prohibitions. ${ }^{194}$ If, however, individualized consideration is not deemed constitutionally required, the extent to which the Court might appropriately extend the categorical exemptions warrants rethinking.

\section{Possible Applications of the Proportionality Doctrine}

There are several ways in which the Court should extend its proportionality doctrine. First, the Court should prohibit the death penalty for any offender under eighteen years of age at the time of her offense. The Court has rejected, by a close margin, the argument that the death penalty is per se excessive retribution for sixteen- and seventeen-year-old offenders. ${ }^{195}$ However, the number of offenders

${ }^{193}$ The Court could have done much more, however, to confine the use of the death penalty for felony murder, which could have further reduced the racial disparities in the distribution of death sentences. See infra note 224.

${ }^{194}$ See Penry v. Lynaugh, 492 U.S. 302, 340 (1989) (plurality opinion) (rejecting a categorical prohibition on the execution of mentally retarded offenders, in part because "[s]o long as sentencers can consider and give effect to mitigating evidence of mental retardation in imposing sentence, an individualized determination whether 'death is the appropriate punishment' can be made in each particular case").

${ }^{195}$ See Stanford v. Kentucky, 492 U.S. 361, 380 (1989) (5-4 decision) ("We discern neither a historical nor a modern societal consensus forbidding the imposition of capital punishment on any person who murders at 16 or 17 years of age.").

The Court has yet to articulate an age below which a state may not execute minors. A year before Stanford, in Thompson v. Oklahoma, 487 U.S. 815 (1988), the Court, by a narrow margin, concluded that the death penalty was excessive for 15-year-old offenders because Oklahoma's capital-punishment statute failed to specify a minimum age at which the commission of a capital offense could lead to a death sentence. See id. at 857-58 (O'Connor, J., concurring in judgment) (explaining that criminal offenders below the age of 16 should not be executed under a statute that failed to provide a minimum age for execution, because it was apparent that the Oklahoma legislature did not carefully consider the issue). The Court failed to conclude, however, that the execution of a 15-year-old was altogether impermissible under the Eighth Amend- 
under eighteen who are sentenced to death is proportionally small, thus underscoring the widespread sense that minor offenders generally lack the culpability to deserve the death penalty. ${ }^{196}$ Although several states allow the execution of minors, ${ }^{197}$ the small number of minor offenders sentenced to death may suggest that those who receive it have been carefully screened by sentencers. ${ }^{198}$ Yet, the same kinds of arguments were available in Coker. Several state legislatures had revealed their willingness to authorize the death penalty for rapists. ${ }^{199}$ The proportion of rapists sentenced to death in Georgia also was not terribly small. ${ }^{200}$ Nonetheless, the four-Justice plurality rejected the death penalty for rapists by emphasizing that the question of evolving decency was ultimately one for the Court. ${ }^{201}$ Under

ment. See id. at 858-59 (O'Connor, J., concurring in judgment) (leaving the question to state legislatures).

${ }^{196}$ See Victor L. Streib, Excluding Juveniles from New York's Impendent Death Penalty, 54 AIB. L. REV. 625, 658 (1990) (noting that executions of persons for crimes committed while they were under age 18 have constituted only about $2.4 \%$ of all executions).

197 The state of the law at the time that the Supreme Court considered the question is described in Justice Brennan's dissenting opinion in Stanford. See Stanford, 492 U.S. at 384-85 (Brennan, J., dissenting) (noting that 12 states prohibited the death penalty for offenders under the age of 18 , that three states did not authorize death for those under 17, that 15 states did not allow the death penalty at all, and that 19 states had the death penalty without any age restriction).

${ }^{193}$ The majority of the Court adopted this view in rejecting the claim for a categorical exclusion of the execution of youthful offenders in Stanford. See id. at 374 (" $[I] t$ is not only possible, but overwhelmingly probable, that the very considerations which induce petitioners and their supporters to believe that death should never be imposed on offenders under 18 cause prosecutors and juries to believe that it should rarely be imposed.").

${ }^{199}$ Louisiana and North Carolina had enacted death-penalty statutes applicable to rape after Furman and several others had simply refrained from including rape in the mandatory death-penalty statutes that they had passed to attempt to comply with Furman. See Coker v. Georgia, 433 U.S. 584, 614-15 (1977) (Burger, C.J., dissenting) (explaining that, because of the uncertainty following Furman, many states have refrained from enacting statutes imposing death for the rape of an adult woman).

${ }^{200}$ In his Coker opinion, Justice White noted that the available evidence from the post-Furman period in Georgia indicated that approximately $10 \%$ of all persons convicted of rape were sentenced to death. See id. at 597 (plurality opinion) (noting that at least nine out of ten juries have not imposed the death sentence in rape cases).

${ }^{201}$ Justice White noted: "These recent events evidencing the attitude of state legislatures and sentencing juries do not wholly determine this controversy, for the Constitution contemplates that in the end our own judgment will be brought to bear on the question of the acceptability of the death penalty under the Eighth Amendment." Id. at 597 (plurality opinion).

It is not certain whether the objective evidence in Coker was sufficient, but only as a prerequisite to further the disproportionality inquiry by the Court, or insufficient to show disproportionality, but overridden by the Court's own judgment of disproportionality. 
the same reasoning, the Court justifiably could have outlawed the execution of minor offenders as cruel and unusual punishment.

The Court should also limit the death penalty to a narrower category of murder. The Justices have done little to exclude lowculpability murderers in the felony-murder category from death eligibility. ${ }^{202}$ Only those offenders brought within the outskirts of felony murder through doctrines of vicarious liability may be protected and, even then, only when they clearly have not acted recklessly or were not substantially involved in the felony. ${ }^{203}$ The existence of a broad sentencing inquiry at which sentencers may grant reprieves helps to rationalize the Court's failure to provide more per se protection. If the capital-sentencing hearing is not required, however, the category of death eligibility should be narrowed appropriately. Limiting the use of the death penalty to murderers who kill intentionally, or kill while intending serious bodily harm, would help to reserve the use of the death penalty to the most culpable murderers.

The Court should also extend the proportionality doctrine to forbid the execution of those who were insane $e^{204}$ at the time of their

${ }^{202}$ For an excellent discussion of the problem, see Rosen, supra note 94 , at $1140-63$.

${ }^{203}$ The extent of these protections was articulated in Tison v. Arizona, 481 U.S. 137 (1987), which modified the earlier holdings in Enmund v. Florida, 458 U.S. 782 (1982), and Cabana v. Bullock, 474 U.S. 376 (1986). For further discussion of these decisions, see supra notes $185-86$ and accompanying text.

${ }^{204}$ Insanity has been defined in various ways, and the prevailing definition in this country has changed over time. The first generally accepted definition was the M'Naghten test announced by the English House of Lords. See M'Naghten's Case, 8 Eng. Rep. 718 (H.L. 1843). Under the M'Naghten test, a person was insane if he was operating under such defective reasoning caused by a mental disease so as: (1) not to know the nature and quality of the act he was performing; or (2) if he did know the nature and quality of the act, he did not know that what he was doing was wrong. See id. at 722. The M'Naghten test of insanity was begrudging, and a few states supplemented it with an "irresistible impulse" test. See, e.g., Commonwealth v. Rogers, 48 Mass. (7 Met.) 500, 502 (1844) ("[T]he question will be... whether the prisoner... acted from an irresistible and uncontrollable impulse...."). In the early 1950s, the United States Court of Appeals for the District of Columbia enacted a much more lenient test of insanity that focused on whether the defendant's act was the "product of mental disease." Durham v. United States, 214 F.2d 862, 875 (D.C. Cir. 1954). This highly problematic test was later abandoned by the District of Columbia Circuit. See United States v. Brawner, 471 F.2d 969, 973 (D.C. Cir. 1972) ("We have decided to adopt the ALI rule as the doctrine excluding responsibility for mental disease or defect...."). The District of Columbia Circuit, like many other jurisdictions, adopted the "substantial capacity" test, proposed by the American Law Institute. See id. (discussing the adoption of the ALI's test that "[a] person is not responsible for criminal conduct if ... as a result of mental disease or defect he lacks substantial capacity either to appreciate the criminality... of his conduct or to conform his 
capital offenses. ${ }^{205}$ The Court has not ruled on this contention, but the issue has become potentially important because several deathpenalty states have abandoned insanity as a defense to conviction on the capital charge. ${ }^{206}$ This means that, under current sentencing doctrine, the defendant's claim of insanity would only constitute a factor for the jury to consider at the sentencing proceeding. Yet, even if the defendant were thought to have been insane at the time of the offense and, on that basis, generally not thought deserving of death, the sentencer could impose the death penalty. The existence of individualized consideration would not ensure that a particular sentencer would focus on offender deserts or, if so, measure deserts consistently with generally existing values. The problem would be even more obvious if individualized sentencing were not required by the Eighth Amendment. The Court should conclude that the execution of one who committed an offense while insane is per se prohibited by the Eighth Amendment.

The Court could also appropriately extend a per se safeguard for mentally retarded offenders. In Penry $v$. Lynaugh, ${ }^{207}$ the Court rejected a mildly retarded capital offender's claim for categorical protection. The Court justified this conclusion, in part, on the ground that Penry's retardation was not serious, as underscored by his jury's conclusion that he was both competent at the time of trial and sane at the

conduct to the requirements of the law'" (quoting MODEL PENAL CODE $\$ 401.1(1)$ (1962))). In the early 1980s, however, after the insanity acquittal of John Hinckley for the shooting of President Reagan, Congress passed a statutory definition of insanity for the federal courts that reverted largely to the M'Naghten test. Under the federal statute, a defendant must prove by clear and convincing evidence that, due to "severe" mental disease or defect, she was unable to "appreciate" either (1) the nature and quality of her conduct or (2) the wrongfulness of her conduct. See 18 U.S.C. $\$ 17$ (a) (1994). For a discussion of the various definitions of insanity and their histories, see DRESSLER, supra note 184, at 316-24.

${ }^{205}$ The Court proscribed the execution of one who is insane at the time of execution in Ford v. Wainwright, 477 U.S. 399, 408-10 (1986), but that holding did not cover offenders who were insane at the time of their offense but later regained their sanity.

${ }^{200}$ These states have abolished insanity as an affirmative defense, but allow defendants to present evidence of a mental illness or defect to negate the existence of the mental state specified in the definition of the crime. See IDAHO CODE § 18-207 (1997); MONT. CODE ANN. § 46-14-102 (1997); UTAH CODE ANN. \$ 76-2-305(1) (1995). Under these statutes, a murder defendant could argue, for example, that she was hallucinating due to a mental illness and, therefore, did not realize that she was killing a person, implying, in turn, that she lacked the requisite mental state.

${ }^{207} 492$ U.S. 302 (1989). 
time of the offense. ${ }^{208}$ The problem with the Court's contention is that the proportionality problem concerns not whether the defendant should receive immunity from conviction, but only whether he should be protected from the death penalty. The Court also cited the lack of evidence in the form of legislation and jury studies indicating opposition to executing mentally retarded offenders. ${ }^{209}$ Yet, Penry presented fairly strong evidence, in the form of public-opinion polls, indicating that a very substantial majority of people in several southern states opposed the execution of the mentally retarded. ${ }^{210}$ The Court plausibly could have concluded that mentally retarded offenders, although criminally responsible, generally lack the culpability to warrant capital punishment.

\section{Potential Problems Facing Expansion of the Proportionality Doctrine}

The Court's expansion of proportionality restrictions would raise some difficult problems. First, any firm lines that the Court would articulate could appear "arbitrary" in that they would not follow any clearly evident demarcations revealed by evidence of societal consensus. Societal opposition to the death penalty is likely to exist along various continuums of gradually decreasing support for the penalty. ${ }^{21}$ A particular line drawn across such a continuum can always be characterized as arbitrary in that similarly situated offenders will fall on either side of it. ${ }^{212}$ If, for example, the Court defined eighteen years as the minimum offender age for death eligibility, a few days in age difference between two offenders might make one offender eligible for the death penalty but the other offender ineligible. ${ }^{213}$ Yet, this

${ }^{203}$ See $i d$. at 333 ("[T]he jury rejected his insanity defense, which reflected their conclusion that Penry knew that his conduct was wrong and was capable of conforming his conduct to the requirements of the law.").

${ }^{209}$ See id. at 333-35.

${ }^{210}$ See id. at 335.

${ }^{211}$ For a discussion of this problem in a different context, see Frederick Schauer, Slippery Slopes, 99 HARV. L. REV. 361, 378-81 (1985).

${ }^{212}$ This problem is represented in the classical Greek paradox of Sorites. A grain of sand is removed from a heap, but even many successive removals of single grains do not remove the heap. When, then, does the removal of a grain render the heap something other than a heap? See id. at 377. Regarding philosophical efforts to articulate an understanding of the paradox, see generally Crispin Wright, LanguageMastery and the Sorites Paradox, in TRUTH AND MEANING 223 (Gareth Evans \& John McDowell eds., 1976).

${ }_{213}$ See, e.g., Joseph L. Hoffmann, On the Perils of Line-Drawing: Juveniles and the Death Penalty, 40 HASTINGS L.J. 229, 245 (1989) (exemplifying this problem by using a case 
sort of arbitrariness ${ }^{214}$ does not warrant abandonment of efforts to define the prerequisites for death eligibility. ${ }^{215}$ It is worth recalling that death eligibility is not a mandate for the imposition of a death sentence. States remain free to provide for further consideration of mitigating factors for offenders within the death-eligible category.

Expanding the categorical exclusions could also be criticized as providing an overly protective prophylaxis not supported by evidence of public consensus. Critics might contend that a categorical ban on the death penalty should find support in objective evidence of nearly uniform public opinion as manifested by the actions of legislatures and juries. Several of the Justices have taken this position in rejecting proposed expansions of current proportionality protections. ${ }^{216}$ The Eighth Amendment, however, does not require this conclusion, and this position largely abandons any role for a constitutional check on

involving two brothers closely related in age who were charged with similar involvement in a capital crime).

${ }^{214}$ It may, indeed, be incorrect to characterize this problem as one involving "arbitrariness." On this point, Professor Schauer's comments are apt:

Although this usage of "arbitrary" is commonplace, I have some reservations about employing that term in this context. The decisions about where to draw the line along a continuous range, although in some sense impressionistic rather than precise, are still based on a process of reasoning. Arbitrariness is relative to domain. Requiring that a certain deliberative body not take action without a two-thirds majority is perhaps arbitrary relative to the choice among two-thirds, sixty-four percent, and sixty-eight percent, but it would still be possible to explain rationally the reasoning process that produces something in this range rather than, say, fifty-one percent or ninety-eight percent. "To the extent that the word "arbitrary" carries a connotation of irrationality, it does not seem to capture what is going on when we gauge where best to place a demarcation along a continuum.

Schauer, supra note 211 , at 380 n.51.

${ }^{215}$ See Rosen, supra note 94, at 1161 (arguing that when the Supreme Court "confronts a problem serious and pervasive enough to require correction in a relatively large number of cases.... [t] he best way to solve [the] problem is to create a firm rule").

${ }^{216}$ See, e.g., Stanford v. Kentucky, 492 U.S. 361, 370-74 (1989) (Scalia, J., joined by Rehnquist, C.J., and White, O'Connor, \& Kennedy, JJ.) (asserting that societal rejection of the death penalty must find support in objective examination of legislation and sentencer determinations, and, on that basis, concluding that the death penalty is not proscribed for those who were 16 or 17 when they committed a capital offense); Penry v. Lynaugh, 492 U.S. 302, 351 (1989) (Scalia, J., joined by Rehnquist, C.J., and White \& Kennedy, J., concurring in part and dissenting in part) (rejecting the claim that mental retardation of an offender categorically bars the death sentence and asserting that a punishment is not "unusual" for Eighth Amendment purposes when "an objective examination of laws and jury determinations fails to demonstrate society's disapproval of it"). 
legislative action. ${ }^{217}$ Even the conclusion reached in Coker, outlawing the death penalty for rape, lacked convincing evidence that legislators and juries were resolutely opposed in all circumstances to punishing rapists with death. ${ }^{218}$ The Court pursued the general consensus-that the capital punishment should be inflicted on only the deservingalthough objective evidence of how that principle applied to rape was not entirely clear. ${ }^{219}$

To serve the value represented by the deserts limitation, the Court could also plausibly articulate prophylactic rules that give a margin of extra protection where the contours of societal consensus are vague. This means, of course, that the prophylactic rule derived from the Constitution may be violated without always, in a strict sense, violating the Constitution. Yet, the use of prophylactic rules in constitutional adjudication is commonplace. ${ }^{220}$ It is difficult to imagine constitutional law developing in any other way. ${ }^{221}$ The holding in Coker itself is a prophylactic rule rather than one conforming precisely to the Eighth Amendment value against retributive excess. Even in death-penalty states not punishing rape with death, the only societal consensus regarding capital punishment as applied to rape is that

${ }^{217}$ On this point, Professor Radin's comments are instructive:

[C]onclusive reliance on these indicators either through substantive definition or extreme judicial deference is circular. Constitutional doctrine may not be formulated by the acts of those institutions which the Constitution is supposed to limit. To glean a list of permissible punishments from those enacted by legislatures either assumes that legislators never enact a punishment they think is, or may be, cruel or allows the legislature to define permissible punishments by its enactments. Such a view removes any role for a constitutional check.

Margaret Jane Radin, The Jurispmedence of Death: Evolving Standards for the Cruel and Unusual Punishments Clause, 126 U. PA. L. REV. 989, 1036 (1978).

${ }^{218}$ There was neither evidence that legislators thought the death penalty was altogether inappropriate for rape, nor evidence that jurors would not impose the death penalty in a significant percentage of rape cases. See supra notes 199-201 and accompanying text.

219 See Fallon, supra note 160 , at 1543 (asserting that the Court acts appropriately in attempting to discern and follow society's deeper values in its job of articulating moral values).

${ }^{220}$ An example is the Court's famous holding that "the prosecution may not use statements... stemming from custodial interrogation of [a] defendant unless it demonstrates the use of procedural safeguards ... to secure the privilege against selfincrimination" in Miranda v. Arizona, 384 U.S. 436, 444 (1966), the prophylactic nature of which is discussed, for example, in Stephen J. Schulhofer, Reconsidering Miranda, 54 U. CHI. L. REv. 435, 446-53 (1987).

${ }^{221}$ For an explanation of why prophylactic rules are a central and necessary aspect of constitutional law, see David A. Strauss, The Ubiquity of Prophylactic Rules, 55 U. CHI. L. REV. 190 (1988). 
rape is not usually punished appropriately with death, not that rape is never appropriately so punished. The same sort of conclusion could be reached regarding youthful offenders, many felony murderers, the insane, and the mentally retarded. Based on the need to articulate prophylactic rules to protect against retributive excess in the use of capital punishment, the Court could extend existing proportionality protections to these categories of offenders.

No conflict exists between the conclusion that the Court properly could extend proportionality protections through prophylactic rules and the conclusion that the Court lacks the authority to regulate the capital-sentencing trial. One might wonder whether the Court could appropriately announce prophylactic protections from death eligibility that do not hew to a clear Eighth Amendment command if the Court could not appropriately create precise decisional rules to be followed by capital sentencers to protect against retributive excess. ${ }^{222}$ Important differences exist, however, between the two approaches. In articulating proportionality rules, the Court only sets low eligibility requirements above which state legislatures may govern the process for selecting those who should die. In attempting to regulate capitalsentencing trials, the Court articulates procedures that cover all decisions to impose death. ${ }^{223}$ The former approach only confines legislative action within reasonable boundaries and, in doing so, rather clearly serves a constitutional function. The latter approach more substantially displaces the legislative prerogative while providing little clear protection against unwarranted decisions to impose death. In pursuit of an Eighth Amendment value, the Court more appropriately could impose a moderate intrusion on the democratic process than a larger one, particularly if the moderate intrusion better serves the constitutional principle.

${ }^{222}$ See supra Part III.B.

${ }^{223}$ As noted earlier, the only theoretically plausible rationale on which the Eighth Amendment regulates the capital-sentencing decision is that the Eighth Amendment protects against undeserved death sentences and that some convicted capital offenders do not deserve the death penalty. See supra Part III.A. However, in deciding whether to control capital-sentencing trials under this view of the Eighth Amendment, the Court still faces an outcome-determinative question. Does the Court know how to specify in any detail who deserves the death penalty and who does not? If the Court is unable to articulate with substantial precision the substantive measure(s) for determining who should die, the reason for regulating the trial under the Eighth Amendment disappears. See supra Part III.B. Alternatively, the Court must articulate a decisional standard to limit who is condemned, which means that the Court articulates a test that guides every decision to impose death and forecloses legislative judgment on this question. 


\section{B. Reducing Inconsistency in the Distribution of Death Sentences}

Critics correctly would note that tightening the prophylactic death-eligibility rules would not eliminate the potential for substantial inconsistency in the distribution of death sentences. Limiting Eighth Amendment restrictions to defining death eligibility, however, would not open floodgates of inconsistency in the distribution of death sentences. As a preliminary matter, it is worth reiterating that consistency or nonarbitrariness in the treatment of capital offenders is not mandated by the Eighth Amendment. Moreover, tightening Eighth Amendment rules on death-eligibility definitions certainly would not produce more inconsistency than under the Court's current Eighth Amendment doctrine. ${ }^{224}$ The Court's regulation of capital-sentencing trials has done very little to ensure consistency between murderers who receive the capital punishment and murderers who are spared. ${ }^{225}$ It is not possible for states to enact systems permitting much more sentencer discretion than is required under current Court doctrine. ${ }^{226}$

Other provisions in the Constitution can also provide some help in reducing inconsistency in the distribution of death sentences. The Court's relatively recent decisions in Turner $v$. Murray ${ }^{227}$ and Batson $v$. Kentucky ${ }^{228}$ help to protect against racial bias by jurors in capital cases. Tumer held that capital defendants accused of interracial crimes are

${ }^{224}$ Tightening the death-eligibility standard for felony murders, see supra notes 9395 , indeed could have a major impact on race-based disparities in capital sentencing because of the cross-racial nature of many felony murders. See Rosen, supra note 94, at 1117-20 (discussing the racial make-up of felony-murder cases compared to that of nonfelony-murder cases).

${ }_{225}$ See supra Part II.A.

${ }^{226}$ Tightening the death-eligibility rules may promote "nonarbitrariness." As already noted, it is uncertain just what it means to say that a capital-sentencing system produces "arbitrary" results. See supra note 214. It is not clear what an "arbitrary" result is until it is clear what the proper standard is for deciding who should be sentenced to death, and the Court has not settled on such a standard. Further, it is not clear how to define the group who is not sentenced to death. Does it include only those who are found guilty of a capital offense, or should it include those who are factually guilty of capital offenses but who are allowed to plead guilty to lesser crimes? Some have argued that the Court's definition of "arbitrariness" is principally concerned with preventing what are akin to undeserved death sentences. See, e.g., McCord, supra note 11, at 573-75 (discussing minimizing overinclusion as the Court's primary concern). If that view is correct, tightening the definition of death eligibility would help promote "consistency" in that it would help ensure that only those who deserve death receive that sanction.

22746 U.S. 28 (1986).

${ }^{228} 476$ U.S. 79 (1986). 
entitled, under the Sixth Amendment right to an impartial jury, ${ }^{229}$ to inform venire members of the race of the victim and to question them about their racial prejudices. ${ }^{230}$ Batson and its progeny have interpreted the Equal Protection Clause to restrict the ability of prosecutors to eliminate minority venire persons with peremptory strikes. ${ }^{231}$ Although these decisions do not foreclose racial discrimination in the overall process of selecting which murderers will die, they provide some protection at the capital-sentencing stage in states that rely on juries to reach the capital-sentencing decision. ${ }^{232}$

${ }^{229}$ The Sixth Amendment provides: "In all criminal prosecutions, the accused shall enjoy the right to a speedy and public trial, by an impartial jury of the State and district wherein the crime shall have been committed...." U.S. CONST. amend. VI. This provision applies to the states through the Fourteenth Amendment. See Taylor v. Louisiana, 419 U.S. 522, 534 (1975) (holding that a state's systematic exclusion from jury duty of women as a class would deprive the defendant of his "Sixth Amendment right to a jury drawn from a fair cross section of the community"). A jury is not required at the sentencing phase of a capital trial. See supra note 178. However, the Court also has concluded that due process requires that a jury, if provided, be impartial even in a context in which a jury is not constitutionally mandated. See Morgan v. Illinois, 504 U.S. 719, 729 (1992) (concluding that barring a capital defendant from asking venire members if they would automatically vote for a death sentence after a guilty verdict violates due process).

${ }^{250}$ See Tumer, 476 U.S. at 36-37 ("We hold that a capital defendant accused of an interracial crime is entitled to have prospective jurors informed of the race of the victim and questioned on the issue of racial bias.").

${ }^{291}$ See Batson, 476 U.S. at 89 (“[T] he State's privilege to strike individual jurors through peremptory challenges, is subject to the commands of the Equal Protection Clause."). A decision by the Court building on Batson held that any criminal defendant could raise the equal-protection challenge, even if the defendant was not of the same race as the excluded venire member. See Powers v. Ohio, 499 U.S. 400, 414 (1991) (noting the Court's recognition that "discrimination in the jury selection process may lead to the reversal of a conviction"). The equal-protection claim also now restricts the use of peremptories based on gender. See J.E.B. v. Alabama ex rel. T.B., 511 U.S. 127, 130-31 (1994) (holding that intentional gender discrimination by state actors in the use of peremptory strikes in jury selection violates the Equal Protection Clause).

${ }^{232}$ Critics would justifiably contend that the protection provided is minor. The protection provided in Turner would help ferret out only venire persons who are willing to confess their racial prejudices, although much racial prejudice is unconscious. See generally Lawrence, supra note 129 . Even when the prejudice is held consciously, the venire member may be ashamed to admit its existence. The practical effect of the Batson holding is reduced because the prosecutor need only give a neutral nondiscriminatory reason for striking the venire member, even if the reason is not very convincing. See, e.g., Deborah A. Ramirez, Excluded Voices: The Disenfranchisement of Ethnic Groups from Jury Service, 1993 WIS. L. REv. 761 (analyzing the Supreme Court's decision in Hernandez v. New York, 500 U.S. 352 (1991), upholding as raceneutral a prosecutor's explanation that he had struck Latino jurors who appeared hesitant when stating that they would not consider their own understanding of witnesses' testimony spoken in Spanish). 
The Court could also improve the fairness of the capital-selection process by demanding better legal representation for capital offenders. A significant disparity exists in the quality of counsel afforded capital offenders. ${ }^{233}$ This disparity contributes to the appearance of inequity in the distribution of death sentences. ${ }^{234}$ The current approach to addressing this problem is generally only to ask post hoc whether counsel's performance has been adequate. ${ }^{235}$ The governing standard for proving inadequate counsel, articulated in Strickland $v$. Washington, ${ }^{236}$ is also difficult for a defendant to meet. To establish ineffective assistance of counsel, a defendant must demonstrate that counsel's performance has been objectively deficient and that the deficiency has prejudiced the defendant. ${ }^{237}$ Strickland has been decried by numerous commentators as providing inadequate protection for defendants-particularly capital defendants. ${ }^{238}$ The Court could impose greater demands for quality representation by altering the Strickland test in favor of capital defendants. ${ }^{299}$ The Court could also hold that states must create systems for providing quality representa-

${ }^{233}$ See, e.g., Vivian Berger, The Chiropractor as Brain Surgeon: Defense Lauyering in Capital Cases, 18 N.Y.U. REV. L. \& SOC. CHANGE 245, 249 (1991) ("[T] he death-penalty context operates-especially in the deep South-to magnify the problems already endemic to indigent defense, thereby fostering 'no-fault' or 'low fault' ineffectiveness on a broad scale."); Stephen B. Bright, Counsel for the Poor: The Death Sentence Not for the Worst Crime but for the Worst Lawyer, 103 YALE L.J. 1835, 1841 (1994) (discussing the pervasive inadequacy of counsel for the poor and the reasons for it); Douglas W. Vick, Poorhouse Justice: Underfunded Indigent Defense Services and Arbitrary Death Sentences, 43 BUFF. L. REV. 329, 380 (1995) ("Resource deprivation of defense services is manifested in different ways in different states, but regardless of the system used, funding for the defense of capital cases is woefully insufficient in most jurisdictions in the United States."); Welsh S. White, Effective Assistance of Counsel in Capital Cases: The Evolving Standard of Care, 1993 U. ILI. L. REV. 323, 32425 ("One of the most striking aspects of our system of capital punishment is the disparity in the quality of representation afforded defendants.").

${ }^{234}$ See, e.g., Steiker \& Steiker, supra note 3, at 421 ("Perhaps the most significant source of inequality in the administration of the death penalty is the unevenness of representation."); Marcia Coyle et al., Fatal Defense: Trial and Error in the Nation's Death Belt, NAT'L L.J., June 11, 1990, at 30 (alluding to the unfairness resulting from the disparity in the quality of trial counsel representing capital defendants).

${ }_{295}$ See Steiker \& Steiker, supra note 3 , at 421 (noting that "the Court has sought to address the representation issue solely by providing for post-trial" evaluation of attorney performance).

${ }^{236} 466$ U.S. 668 (1984).

${ }^{237}$ See id. at 687 (setting out the test for ineffective assistance of counsel).

${ }^{238}$ See Louis D. Bilionis \& Richard A. Rosen, Lawyers, Arbitrariness, and the Eighth Amendment, 75 TEX. L. REV. 1301, 1306 n.20 (1997) (listing authorities in which Strickland has been criticized as inadequate protection for capital defendants).

${ }^{239}$ For an argument of this sort, see, for example, White, supra note 233 , at 376-78. 
tion to capital defendants. ${ }^{240}$ The Court could easily conclude that the right to counsel requires heightened protection for defendants in the capital context. On several occasions, the Court has noted that "death is different" from other forms of punishment so as to require heightened reliability, ${ }^{24 l}$ and the Court could employ this rationale to require more consistent, quality representation by counsel. ${ }^{242}$ This mandate of quality counsel would emanate from the Sixth Amendment, ${ }^{243}$ although the requirement would also serve the Eighth Amendment goal of assuring that only deserving offenders receive the death penalty. ${ }^{244}$

${ }^{210}$ For recent commentary favoring this approach, see, for example, Bilionis \& Rosen, supra note 238, at 1311-12, and Steiker \& Steiker, supra note 3, at 421-22.

${ }^{241}$ See, e.g., Turner v. Murray, 476 U.S. 28, 37 (1986) (invalidating a death sentence as violative of the Sixth Amendment right to an impartial jury where a black defendant charged with an interracial crime was not allowed to question potential jurors about their racial prejudices); Beck v. Alabama, 447 U.S. 625, 637-38 (1980) (invalidating a death sentence under the Due Process Clause because the state jury was not permitted to consider a verdict of guilt on a lesser included offense); Gardner v. Florida, 430 U.S. 349, 357-62 (1977) (invalidating a death sentence under the Due Process Clause based on the failure to reveal to the defense counsel a pre-sentence report on which the sentencing judge purported to rely).

${ }^{212}$ Although mandatory sentencing is permissible in the noncapital context, a defendant has the right to counsel at sentencing. See Mempa v. Rhay, 389 U.S. 128, 137 (1967) (noting this requirement in a case which can be characterized either as a "revocation of probation" or a "deferred sentencing"). Thus, although I have argued that the Eighth Amendment should never have been understood to foreclose death sentences mandatory upon conviction, this would not eliminate the right to counsel at sentencing hearings.

${ }^{245}$ The Sixth Amendment provides: "In all criminal prosecutions, the accused shall ... have the Assistance of Counsel for his defense." U.S. CONST. amend. VI. The Court has held that this provision applies to the states through the Due Process Clause of the Fourteenth Amendment. See, e.g., Gideon v. Wainwright, 372 U.S. 335, 344 (1963) (holding that the Sixth Amendment right to counsel is "fundamental and essential to fair trials," and therefore is applicable to all felony defendants prosecuted in state courts).

${ }^{244}$ The mandate is properly grounded in the Sixth Amendment because that is the provision directly articulating the requirement of quality counsel. Unevenness of counsel can be thought to contribute to the "arbitrary" or "inconsistent" distribution of death sentences. Nonetheless, even if accepted as a valid interpretation of the Eighth Amendment, which it is not, a "nonarbitrariness" or "consistency" goal would not necessarily call for consistently high-quality representation of capital defendants. If the Eighth Amendment were only concerned with "nonarbitrariness" or "consistency" as those terms are conventionally understood, consistently poor defense lawyering, just as with consistently good lawyering, would provide consistency of representation across cases. The true Eighth Amendment value applicable to the selection process in capital cases, of course, is that only defendants who deserve the death penalty should receive that sanction. Providing high-quality counsel for all capital defendants serves this Eighth Amendment value. One could conclude that the Eighth Amendment requires quality counsel to protect the deserts-limitation ideal. However, 
The Equal Protection Clause, of course, would also continue to pose limits on inequality in the distribution of death sentences, and the equal-protection context is the proper place for arguments about most equality commands. ${ }^{245}$ Critics of the death penalty as currently applied might argue that equal protection should extend beyond purposeful discrimination to require capital-sentencing systems that do not produce significant disparities based on factors such as race. In McCleskey v. Kemp ${ }^{246}$ the Supreme Court rejected this contention. ${ }^{247}$ Although precedent did not strongly support the contention that McCleskey was denied equal protection, ${ }^{248}$ one could disagree with the Court's view of equal protection as not extending beyond purposeful discrimination by decisionmakers in the capital-selection process. ${ }^{249}$

the Sixth Amendment provides a more direct mandate for high-quality counsel in capital cases than the Eighth Amendment. Cf. Turner v. Murray, 476 U.S. 28, 37 (1986) (invalidating death sentence, but not conviction, of a black defendant charged with killing a white victim, because the trial court's refusal to allow questioning of potential jurors regarding their racial prejudices violated not the Eighth Amendment but the Sixth Amendment right to an impartial jury).

${ }^{245}$ See Gross \& Mauro, supra note 131, at 114-15 (giving examples of racial classifications in a capital-selection process which would be explicit and, therefore, clearly violative of equal protection).

246481 U.S. 279 (1987).

${ }^{247}$ Regarding the equal-protection claim in McCleskey's petition, the majority said that proof was required "that the decisionmakers in his case acted with discriminatory purpose." Id. at 292. The Court's opinion would seemingly allow establishment of a prima facie case of discriminatory purpose based on statistical analysis of a particular prosecutor's resolution of numerous earlier capital cases. The Court rejected the notion, however, that system-wide statistics regarding decisions by numerous prosecutors and sentencing juries could make out even a prima facie case of intentional discrimination by a particular prosecutor or sentencing jury. See id. at 319 ("Despite McCleskey's wide-ranging arguments ... the only question before us is whether in his case ... the law of Georgia was properly applied." (citation omitted)).

${ }^{248}$ As Professor Randall Kennedy has aptly noted:

If $\mathrm{McCleskey} \mathrm{disappoints,} \mathrm{it} \mathrm{should} \mathrm{do} \mathrm{so} \mathrm{on} \mathrm{some} \mathrm{basis} \mathrm{other} \mathrm{than} \mathrm{tradi-}$ tion, for the majority cannot rightly be accused of promulgating a startling ruling. To the contrary, $\mathrm{McCleskey} \mathrm{was} \mathrm{all} \mathrm{too} \mathrm{predictable.} \mathrm{Its} \mathrm{critics} \mathrm{must} \mathrm{face}$ the fact that, as far as reported cases disclose, defendants rarely, verging on never, succeed in challenging punishments using arguments of the sort voiced by Warren McCleskey's attorneys.

KENNEDY, supra note 117 , at 340 .

${ }^{249}$ For the argument of two commentators who take this position, see Gross \& Mauro, supra note 131 , at 117.

A serious effort to achieve consistency in capital sentencing, however, raises a variety of troubling problems that only add to the questions about its propriety as constitutional doctrine. See id. at 123-26 (suggesting that de facto abolition of the death penalty might be the only effective remedy); see also Scott $W$. Howe, The Constitution and Capital Sentencing: Pursuing Justice and Equality, 60 FORDHAM L. REv. 749, 772- 
The ultimate irony, however, of pursuing consistency as the goal for regulating capital sentencing (as opposed to abolishing capital punishment) is that in the long run, the endeavor cuts at least as much in favor of increased use of the death penalty, and mostly on minority defendants, as it does in favor of reduced use of the death penalty. ${ }^{250}$ As Professor Randall Kennedy has clarified, the Baldus study, upon which the $M c$ Cleskey case relied, ${ }^{251}$ said at least as much about the inequitable treatment of black murder victims as it said about the inequitable treatment of black murderers. ${ }^{252}$ The data showed that the race of the victim was, by far, the primary racial influence at work in the aggregate of capital cases from Georgia. ${ }^{253}$ Killers of white victims were much more likely to get the death penalty than killers of black victims. ${ }^{254}$ Although among murderers who killed white victims, black defendants were disproportionately condemned, the race-of-victim factor heavily favored black murder defendants as a group because black murderers typically killed black

78 (1992) (discussing problems of defining consistency and providing an appropriate remedy); Kennedy, supra note 107, at 1429-40 (discussing the problem of devising an acceptable remedy).

${ }^{250}$ As for legislative attempts to require consistency in capital sentencing, the Racial Justice Act, S. 1249, 102d Cong. (1991), reprinted in 137 CONG. REC. S7381-82 (daily ed. June 6, 1991), would have allowed a capital defendant to use state-wide statistical evidence to establish a prima facie showing that her death sentence resulted from racial discrimination and, unless that showing were rebutted, to have her death sentence vacated. See id. § 3(a), reprinted in 137 CONG. REC. S7381-82 (daily ed. June 6, 1991). The act was defeated by proponents of the death penalty. See 137 CONG. REC. S8300 (daily ed. June 20, 1991). A similar bill was subsequently introduced but then removed from the 1991 omnibus crime bill. See Clifford Krauss, House Approves AntiCrime Bill with Something for Both Camps, N.Y. TIMES, Oct. 23, 1991, at A1. Another bill was introduced but then removed from a 1994 omnibus crime bill. See Bryan Denison, Since Days of "Old Sparky," Racial Issue Survives: Questions About Faimess Unresolved Even Today, HouS. POST, Oct. 16, 1994, at A2, available in LEXIS, News Library, Houpst File.

${ }^{251}$ As for the nature of the Baldus study, see supra notes 107-12 and accompanying text.

${ }^{252}$ Professor Kennedy noted: "The defendant-centered paradigm [in the McCleskey case] never allowed the victimization of the black community to reach the surface of the debate. Yet the state's response to the murder of members of that community is precisely what the race-of-the-victim statistics chart." Kennedy, supra note 107, at 1422 (footnote omitted).

${ }^{253}$ See supra notes 107-12 and accompanying text.

${ }^{254}$ As previously indicated, out of 981 white-victim murder cases brought between 1973 and 1979, 108 of them, or $11 \%$, resulted in death sentences. In contrast, out of 1503 black-victim murder cases brought during the same period, only 20 of them, or a little over $1 \%$, resulted in death sentences. See supra note 108. 
victims, and the black-victim category accounted for most murders. ${ }^{255}$ Of course, the disproportionately low distribution of capital sentences against killers of black victims could be solved through increased use of the death penalty in black-victim cases. ${ }^{256}$ Yet, this solution would likely increase the percentage of death sentences imposed on black defendants and would surely increase the overall use of the death penalty. ${ }^{257}$ An important message worth contemplating, then, is that under both the Equal Protection Clause and the Eighth Amendment, seriously pursuing consistency as the goal for regulating capital sentencing is, at least in the long run, potentially pro-death penalty. ${ }^{258}$

\section{CONCLUSION}

The effort of the Supreme Court to guide capital sentencing under the Eighth Amendment was destined to fail. The Court has not given the Eighth Amendment a fair chance. It has never arrived at a

${ }^{255}$ Out of 2484 murder cases brought between 1973 and 1979, 1503 of them $(60 \%)$ were cases involving black victims. Of the 1503 black-victim cases, 1443 of them (96\%) involved black defendants. See supra note 108.

${ }^{255}$ See Kennedy, supra note 107, at 1436 (noting that a "level-up" solution could build "on the assumption that put to a choice, jurisdictions committed to capital punishment would opt to increase the level of capital sentencing for black-victim murders rather than abolish capital punishment or lower the level of capital sentencing for white-victim murders").

257 This conclusion would remain true even if in the white-victim cases, the deathsentencing rate for black defendants were reduced to the same rate as that for white defendants and the death-sentencing rate for black-victim cases then only tracked the death-sentencing rate for white-victim cases. Within the white-victim cases, the researchers estimated that, after controlling for other seemingly relevant variables, a black defendant was 2.4 times more likely to receive a death penalty than a white defendant. See BALDUS STUDY, supra note 64, at 328 . However, the much greater aggregate influence was the race of the victim. The researchers estimated that a defendant who killed a white person was for that reason alone 4.3 times more likely to receive a death sentence than a defendant who killed a black person. See id. at 324 . Because, as the table in footnote 108 reveals, the vast majority of murder cases involved black victims, a death-sentencing rate equal to that resulting in the whitedefendant-white-victim cases would result in an increase in the number of death sentences imposed. See supra note 108.

${ }^{258}$ Using race-conscious techniques to produce results that would provide "equal protection" to the community of actual and potential black victims would raise troubling questions. Yet, not every sort of "level-up" solution would violate the Constitution. Indeed, some prominent scholars have argued that a "level-up" approach to preventing race-of-the-victim discrimination would be preferable to the state of affairs produced by McCleskey. See, e.g., Kennedy, supra note 107, at 1439 ("[D]espite risks that would have to be carefully monitored, a level-up remedy for race-of-the-victim disparities would be far preferable to the situation bequeathed to us by the McCleskey Court."). 
plausible theory about how the Eighth Amendment regulates capital sentencing. The Court has typically asserted that the aim is to achieve "nonarbitrariness" or "consistency" in the use of the death penalty. Yet, this stated goal does not describe what the Court has actually accomplished, for capital sentencers can be-and are-given virtually as much discretion under the Court's Eighth Amendment doctrine as they were given in the pre-Furman era. The failure of the Court to pursue consistency, except in its rhetoric, derives not only from the difficulty of the task, but also from the incongruity of that goal with Eighth Amendment values. Consistent treatment of capital offenders can be achieved by executing all of them. Unless a substantive Eighth Amendment standard exists by which to distinguish among capital offenders-a view that the Court has not endorsed-one cannot complain on consistency grounds about the offenders' uniformly harsh treatment. The irony of concluding that uniformly harsh treatment of all capital offenders could result from a protection against "cruel and unusual punishments" underscores that consistency is not the operative Eighth Amendment value.

The true Eighth Amendment protection that bears on capital sentencing is the prohibition on retributive excess. In the death-penalty context, this prohibition means that offenders should not suffer death sentences that they do not deserve, which is essentially to say that offenders are not appropriately sentenced to death because of utilitarian interests. Further, this deserts-limitation principle does not call for consistent treatment of capital offenders; it operates only as a limitation on decisions to impose death, not as a limitation on decisions to refrain from imposing death. Significant aspects of the Court's decisions do not coincide with the deserts limitation, but this principle explains much more of the Court's current doctrine than the consistency theory.

Although the deserts limitation appropriately guides capital sentencers, it cannot justify intrusion by the Court into the administration of capital-sentencing trials. The difficulty grows from the inability of the Court to define with substantial precision how to measure offender deserts. The Court has been unable to describe how capital sentencers should weigh various, and often competing, evidentiary factors to pursue the deserts inquiry. Indeed, the Court has not even been able to describe what evidence is truly relevant, in the sense that the capital sentencer must actually weigh it in reaching a decision. The Eighth Amendment value is grounded in an effort to pursue societal consensus, but the societal consensus in favor of the 
deserts limitation does not translate into refined rules at these more exacting levels. Yet, the Court should be able to discern fairly precise rules before it seeks to enforce the deserts limitation at the capitalsentencing trial. The Eighth Amendment rationale for preventing legislatures from specifying the rules disintegrates if the Court cannot say what the rules should be.

The Court can legitimately enforce Eighth Amendment restrictions on who is subject to the death penalty. The proper domain of the Court lies in drawing categorical lines defining relatively precisely which offenders are death-eligible. The Court has appropriately employed the deserts-limitation ideal to articulate and enforce these kinds of per se rules under the Eighth Amendment. Rather than providing a capital-sentencing trial to attempt to enforce the deserts limitation, the Court should have focused on expanding these deatheligibility protections.

The Court's experiment with capital-sentencing regulation counts among its major modern failures. The Court has accomplished very little of value, after investing vast judicial resources. ${ }^{259}$ When Furman was decided, some observers believed that the Court could promote substantial consistency in the use of capital punishment to secure equity for powerless defendants. In retrospect, that confidence reflected a misperception both about the disparities at work in the distribution of death penalties and about the difficulty of reducing them. The Court should acknowledge the incongruity between the proclaimed goal of substantial consistency and what the Court's doctrine actually achieves. The Court could try to address the conflict by more vigorously pursuing consistency, but that goal lacks a grounding in the Eighth Amendment. The Court would do better by concluding that its goal is not to achieve consistency, but rather to protect against undeserved death sentences, which is the true Eighth Amendment value that bears on capital sentencing. In the end, however, the

${ }^{239}$ No serious student of the Court's capital-sentencing doctrine could accept as sincere the Court's continuing claims of pursuing "nonarbitrariness" or "consistency" in the distribution of death sentences. As two thoughtful scholars of the death penalty have recently noted:

The Supreme Court's death penalty law, by creating an impression of enormous regulatory effort while achieving negligible regulatory effects, effectively obscures the true nature of our capital sentencing system, in which the pre-

Furman world of unreviewable sentencer discretion lives on, with much the same consequences in terms of arbitrary and discriminatory sentencing patterns.

Steiker \& Steiker, supra note 3, at 436. 
Court's inability to refine significantly the deserts limitation destines it to failure in the effort to use the Eighth Amendment to regulate the capital-sentencing proceeding. 
$* * * * * * *$ 